日本組織学記録, 巻 24, 号 2 (昭和 38 年 12 月). 頁 $155-185$.

Arch. histol. jap. Vol. 24, n. 2 (December 1963). P. 155-185.

群馬大学医学部耳鼻咽喉科学教室 (主任: 石井英男教授).

Dept. of Oto-R hino-Laryngol. (Director : Prof. H. ISHII),

Sch. of Med., Gunma Univ., Maebashi.

\title{
人の気管腺の組織学的並びに細胞学的研究。
}

\section{Histological and Cytological Studies on Human Tracheal Glands.}

\section{金子寛 Hiroshi KANEKO.}

(Received November 16, 1963.)

人の気管腺 (Glandulae tracheales) は気管粘膜の粘膜下組織内に存在する腺であ る。粘膜上皮に関してはかなり詳細な細胞学的研究があるが，気管腺に就いては 報告が少なく，その記述も簡単なあののみである. 古く Tarchetti (1871) によ り 2 種類の腺細胞が見出され，Frankenhäuser（1879）により大部分は粘膜下組織 内に, 一部小腺が粘膜内に存在し，大きい腺は軟骨間腔に $3-5$ 列の層をなして 存在すると記載された，腺の性質については Waller と Björkman (1882) により 始めて混合腺であることが明らかにされた。現在では気管腺は喉頭腺に極めて類 似した混合腺であって，微細な弾性線維で包まれると権威ある成書にも記されて いるが (Schumacher 1925, Heiss 1936)，しかしその組織学的細胞学的事項に関す る詳細な研究は見当たらず，ただ森 (1952) の「人の気管腺は胞状管状腺であり, 終末部は 1 部は混合腺，1 部は漿液腺，1 部は粘液腺である」との記載を見るのみ である、以上の如き研究状態に鑑み，著者は人の気管腺の轷細な形態学的研究の 必要を痛感し，観察を行なう機会を得たので，その結果を報告する.

\section{I. 研究材料と方法.}

材料は気管切開術或いは喉頭全摘出術に際して気管断端より採取した健常な気 管粘膜で，36才より 76 才までの男女 25 例のものである。手術時の粘膜に対する 諸影響の最も少ないと思われる部位を選び，材料に対する侵襲を出来るだけ少な くするように努力した。 全身麻酔下の喉頭全摘出術時にはかなり下部の粘膜も採 取しえた。腺組織への影響は最小限に留めえたものと考えて居る。なお 2 例は屍 体 (死後約 12 時間) より得られたものであるが，気管に病変なく，気管分岐部の 直上部の粘膜を入手しえて研究に供した。採取部位は前壁及び側壁の気管軟骨部 及び軟骨間部，更に後壁の膜性壁である。

材料は採取後なるべく速かに Levi 氏液, Zenker-formol, formol-alcohol, $10 \%$ formalin, Champy 氏液で固定した. Golgi 装置の検出には小切片を Champy 氏液で 24 時間固定した後, Kolatchev 氏法に従い，1％オスミウム酸で $36^{\circ} \mathrm{C}$ に保って 
6ー7 日間 osmieren した。固定組織片は総べてアルコールで脱水し, キシロール

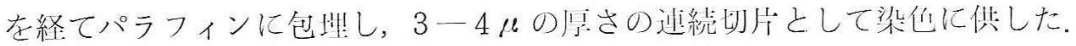

一般的钼祭には Zenker-formol, $10 \%$ formalin に间定した切片に hematoxylineosin 染色を用い，微細棈造の検祭のためには Levi 氏液に固定した切片に Heidenhain 氏鉄 hematoxylin 染色, azan 染色を用いた。更に組織化学的検案には Zenkerformol, $10 \%$ formalin, formol-alcohol 等で固定したものに逈沃度酸 Srhiff 反応

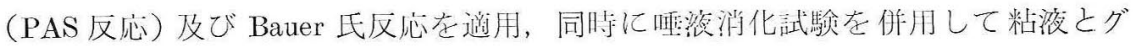
リコーゲンの鑑则を行なった。系䊀休と分泌颗䊀，Golgi 装置と分泌頪档の関係 の钼察には，上記諸染出法の他に，それぞ扎 Bauer 氏反応後に Heidenhain 氏敛 hematoxylin 染仙をはどこしたあの（伊東 1940），文び Kolatchev 氏オスミウム睃 法で Golgi 装置を検出した楞本に Kull 氏 anilinfuchsin aurantia 染色をほどこし たものを用いた。

\section{II. 自家 所見.}

\section{A. 組 織学的所見.}

a) 腺の存在位置と広がり方.

人の気營腺は主に気管の粘膜下組織内にあり，腺の広がり方は一般に気管軟骨 の存在に左右され，軟骨の存在する部，上下軟骨の閒の部，食道に接する膜性壁 の条部で，それぞれ広がり方異にする。すなわち軟骨の存在する部位では粘膜

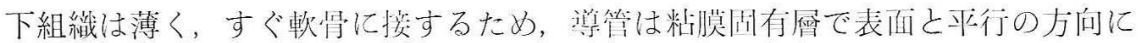
届折し，腺体は表而または軟骨膜と平行の力向に広がる。軟骨間部に於いては上。

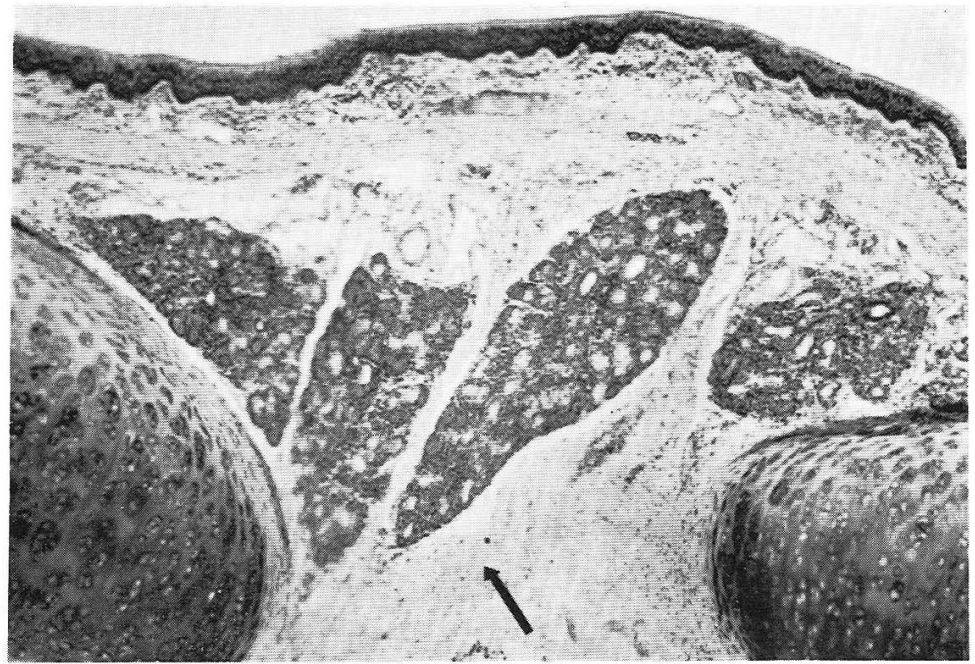

Fig. 1. Tracheal glands in the intercartilaginous region, they extend to the inner surface of the Lig. anulare $(\uparrow)$. ZENKER-formol, hematoxylin (HANSEN)-eosin. 
下軟骨は輪状䩒带 (Ligamenta anularia trachealia) により結合され，この部では粘 膜は厚く，腺は軟骨間にやや深く入り，輸状靱带に接しているものすあるが，靶 苧を貫通して外一広がる腺は無い（図1）。軟骨間部では軟骨の端より斜ðに伸び て入り込んで来る腺も少なくない，粘膜が比較的厚い膜性壁では，表直に平行に 広がるものの他に，深く垂直力向へ仲び広がるものが多く，粘膜下組織内のみに とどまらず，平滑筇層（M. trachealis）の中に広がるもの，更にこの筋嬮を貫いて 外側の外脱にまで広がるものも少なくはない，膜性壁に存在する腺には極めて大

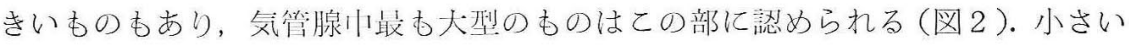
あのが多いのは軟省部であるが，表 西に平行に浅く広がるとはいえ，か なり大きい腺も認められた。膜性壁 に於いて更に外膜を破り传道壁にま で侵人する腺は浔められなかつた。 また伶道腺に於ける腺が食道の長軸 の力向に長く伸びているという報告 （横地 1954）と比較すべき听見，す なわち気管の長軸と平行して縦にの びている腺が特に多いとは言いえな い，気管にては腺の㕕驾りうは軟骨 の存在と密接な関係老搏つが，父管 の長軸とは関係は無いようである。

1879 年. Frankenhäusər が見出し ているような上皮内腺は粘膜表西酒に は浔められなかったが，著者は粘膜 上皮楩山の壁にそれらしい棈造を見 出した (図 3 ). 乙れは深部の腺の開 山部汃と屯考えられたが，遇続㑑本 に依り上艾内腺であるととが倠めら れた，侀しこの上艾内腺と思われる むのの上攴は䋊毛縕胞在有する。

\section{b) 腺の椾口部.}

脉は奨管を経て開口する。軟学部

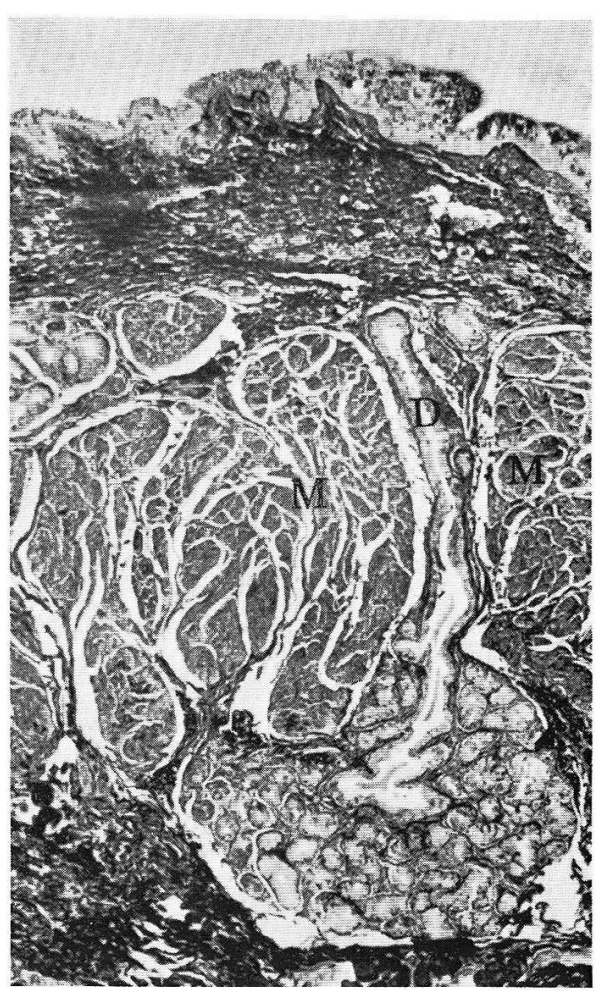

Fig. 2. A tracheal gland in the paries membranaceus, the excretory duct $(D)$ penetrate the smooth muscle layer $(M)$ and the glandular body is found outside of the muscle layer. LEVI, iron-hematoxylin (HEIDENHAIN). $\times 48$ の浅い腺も膜性壁の深い大きい腺もすべて奨管を有している。奨管は表面上皮の 伯凹部の中に開いする。この上皮陷凹には，浅い管状や漏斗状のものから，深い管

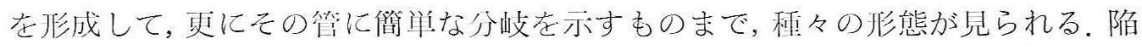
凹部圭蕧う上皮は粘膜表面上皮之同じ性犋を示し，多列蟣毛上皮で明膫な基底膜

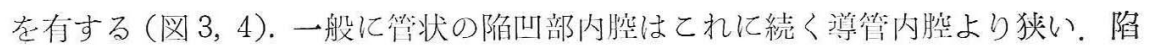




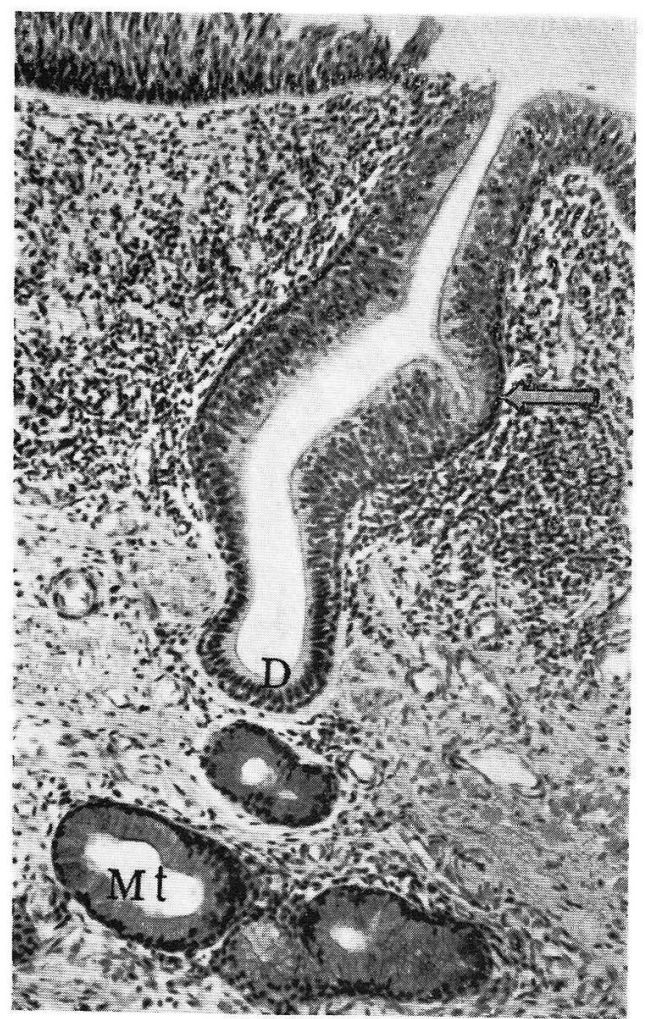

山は膜性壁に於いてはかなり深部 にまで艋值ひ伸ているあのああ るが, 軟骨部に於ては, 比較的浅 く腺体や㧳管が表面に平行に広が っている場合であ，上支陌山はは ぼ更直の方向在とる。深い管状陌 山で粘膜下組織に深く伸びて分岐 を示すものもその内腔表面はやは

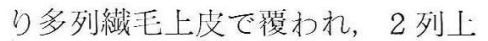
度からなる殞管しの境界は明睹で ある(脳 3 )。

\section{c) 翟袜。}

梁管は腺管よりも太く広い内腔

Fig. 3. A deep tubular epithelial crypt is covered by a pseudo-stratified columnar ciliated epithelium, and at the bottom of it opens a excretory duct $(D)$. In the crypt epithelium, a intraepithelial gland is seen ( $\uparrow$ ). $M t$ mucous glandular tubules. ZENKER-formol, hematoxyl in (HANSEN)-eosin. $\times 120$

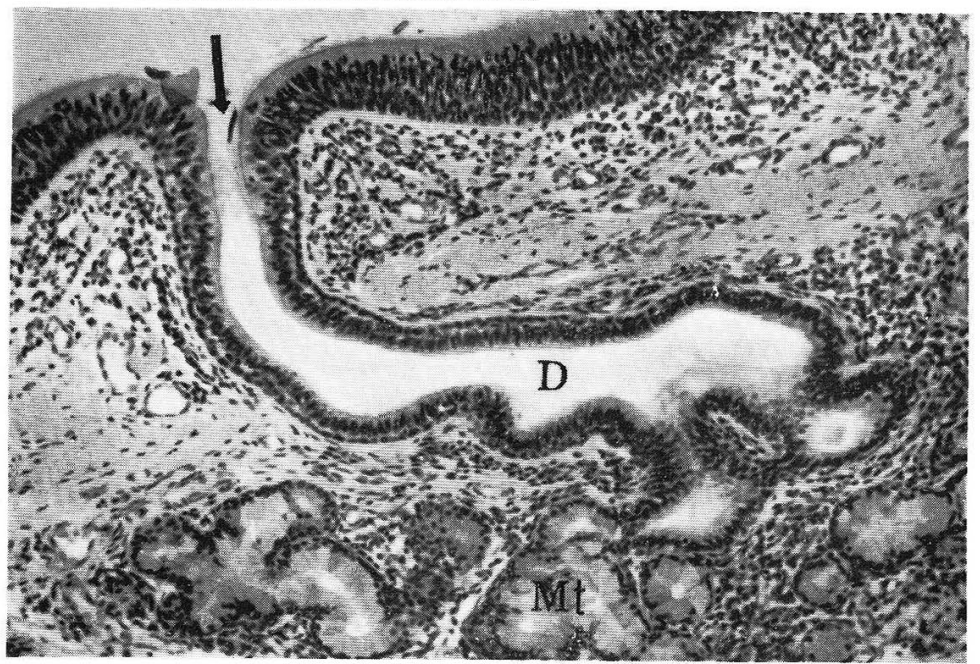

Fig. 4. A tracheal gland in the cartilaginous region. The excretory duct $(D)$, lined with the simple columnar epithelium with a basal cell layer, runs parallel to the mucosa surface, opens in the bottom of epithelial crypt $(\uparrow)$ and shows simple branching. $M t$ mucous glandular tubules. ZENKER-formol, hematoxylin (HANSEN)-eosin. $\times 120$ 
を持ち，開口する上皮陷凹よりも広い管腔を有する．腺体から種々の彎曲を示し つつ開口部に向うが, 軟骨部の浅い腺では比較的短かく, 彎曲む少なく, 腺体よ り出て表面之平行して走り, 陷凹に開口する直前で表面に向加って屈折し（図 4), 垂直方向に伸びて米た陥凹に接続する，膜性壁に於いては導管は長く，哚部の腺 体より平滑筋層を貫通して上皮陥凹に達する，導管は殆んど分岐を示さないが， 一部に簡単な一次的分岐を示すものがある。分岐は膜性壁の深い大きい腺に多い が (図 2 ), 軟骨部の浅い腺にも認められる(図 4). 従って人の気管腺は大部分が 単腺で, 1 部が複腺であると考えられる，また導管が深部に向って走る途中，数 筒の腺管 (終末部) がこれより出る場合もあるが, 何ら腺管の派生を見ずに木梢 に達するものあある。導管上皮と陌凹を作る表面上皮との境界は明暸である。す なわち管状或いは漏斗状の陌凹部よりも導管内腔の方が一般に広く, 時に囊状に

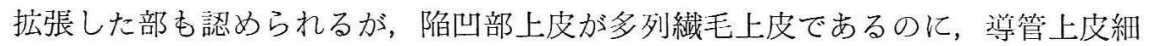
胞は 2 列に业び, 繊毛はなく, 導管はその全長のいずこにも繊毛細胞は出現しな い。また陷凹部には表面上皮と同じ厚い明瞭な基底膜が存在するが，桨管の周团 には終末部より連続する固有膜があるのみである。

導管上皮は高い円柱上皮細胞とその基底部に存在する基底細胞との 2 列上皮で ある、多層を示すことはない、管腔に面する円柱上皮細胞は密に並列し，細長で， 導管内腔が拡大した部仿に於いても扁平化することは無く, 円柱形を保つ。円柱 上皮細胞の核は榰円形ないし長楕円形で, 細胞の中央部或いはやや基底部に偏在 し，1-2筒の核小体を有する。相接した円柱上皮細胞の遊離表面間には閉鎖堤 在認める。細胞質は eosin に淡染する。細胞質内にグリコーゲンは証明されない が. 円柱上皮細胞の中には種々の量の唾液消化耐性 PAS 陽性物質を含有するも のがあり，主に核直上部から管腔面に至るまでの問に分布する（図 5 ). このPAS 陽性物質が分泌物であるか否かは不 明であり，分泌機能の存在を思わし める分泌像は見られなかった。細胞 の核上部には簡単な彎曲を示す明細 管, すなわち Golgi 装置の陰像が認 められる (図 6). Kolatchev 氏法によ る標本ではオスミウム酸で黒化した Golgi 装置を認めるが, 腺細胞に見 られるほよ゙複雑な網状或いは系球状 の北は示さず，小さくやや簡単な網 状或いは管腔側へ開いた C 字状ない し U 字状の彎曲を示した索状を呈 し, どの円柱細胞であその形態棈造 は殆ど等しく，変化にそしい，細胞

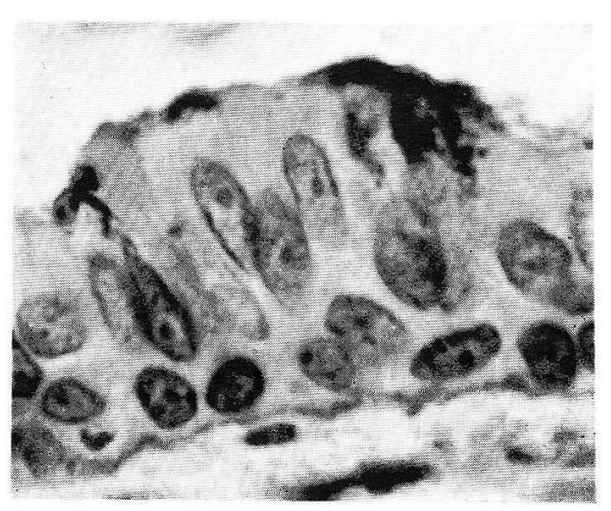

Fig. 5. Simple columnar epithelium of a excretory duct with a basal cell layer. In the supranuclear region and the apical end of the columnar cells PASpositive substance (dark) is seen. Formol-alcohol, PAS-hematoxylin (HANSEN). $\times 1,080$ 


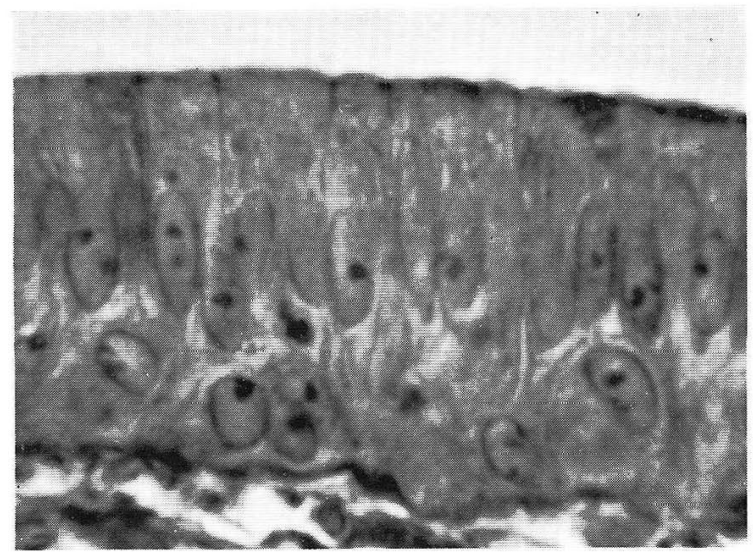

Fig. 6. The same epithelium of a excretory duct as shown in Fig. 5. GOLGI negatives (clear canaliculi) are visible in the supranuclear region of the columnar cells. LEVI, iron-hematoxylin (HEIDENHAIN). $\times 1,080$

内には少数のリポイド顆 粒脂肪滴が時に涩められ る. 大きさはいろいろで, 主に核の管腔侧に見られ る。 円柱上皮細胞の基底 部に 1 層の基底細胞が並 び，その基底面は等管の 闾有膜に接宁可。其底細 胞低く，立广形或いは やや刑平で，学管開口部 付泛では密に並び，立方 形を呈し，深部では開ら 部に比較して唒列は疎と なる。しかし筫管上皮が 门柱上支細胞のみから成 り，共底細胞を全く久き，単層上皮であることはない，基底細胞の核は円形，楕円 形，腎形などで，細胞質に之しい，分泌像はない，なお導管上皮の円柱細胞の間 に，数個の粘液細胞からなる細胞群が介在するのを認めた。 円柱細胞と同様に 1 列に並び，時にこの部では基底細胞を欠く。との細胞は Bauer 氏反応によって紅 紫色に染まる，粘液頪粒で允満し，顆粒により核は基底部に长迫されて具型的な 粘液細胞の形態を示す。乙れ等の粘液絸胞は沽管の開口部に近い部位にも，また 末梢の腺管（終末部）に江い部位にも出垷する。

人の気管腺に於いては，懔管に続いて線条部在持つ腺は見出しえなかった。

d) 腺管（終末部）と腺細胞.

導管に続いて腺管（終末部），すなわち分泌管がある。人の気管腺ではすべて腺

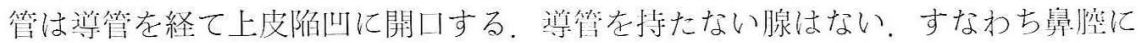
於ける小腺に相当する腺は認められなかった (岩井 1953 参涠)。渻管の分岐は無 いか或いは簡単な一次的なものであるが，腺管には複篗な分岐老見る（四７）。軟

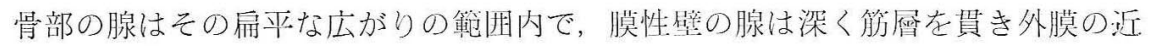
くにまで広がって，極めて複集に分岐する(分岐腺). 腺管はその中央に種々の広 さの腺腔有し，管状で (管状腺)，その末端は更に管状或いは胞状の分泌部（終 末部）に分岐する (管状胞状腺)，以上の所見から人の気管腺は棌管の分岐が無い 時は単分岐管状胞状腺，薄管の分岐がある洔は複分岐管状胞状腺である。腺管の 内腔の広さには狭いものから囊状に拡张したものまで種々の太さのものが見られ るが，一般に等管よりは狄い，腺管は迁曲し，分岐して，切片上円形，櫴円形，管 状など，いろいろの断面を呈する。

腺管，すなわち分泌部の腺上文を形成する腺細胞は円柱形或いは立非で，1 
層に配列し，粘液細胞と漿液 細胞の 2 種類がある。両種腺 細胞の鑑別は主として分泌顆 粒と核の非に低る。分泌過程 にあって，細胞質内に分泌顆 粒が出現し, 分泌像を示す細 胞に於いては鑑別は容易であ るが，顆粒を持たない分泌機 能休止状態にあるものでは軕 者の鑑別は極めてむづかし い。粘液顆䊀（分泌顆粒）は hematoxylin-eosin, 鉄 hematoxylin, azan 染色等では染色 されにくく，僅に hematoxylin, anilin 青に淡染し, 細胞 質は明るく泡沫様に見え；粘 液顆精で允渾した細胞では核 は顆粒により細胞の基底部へ 圧排され，濃維し，三们非或 いは不規則な扁平形在呈す 吕，他方漿液細胞はその分泌 顆粒(漿液顆粒) が eosin 飞染 まり，鉙 hematoxylin 染色で は深青色に強染するので暗調

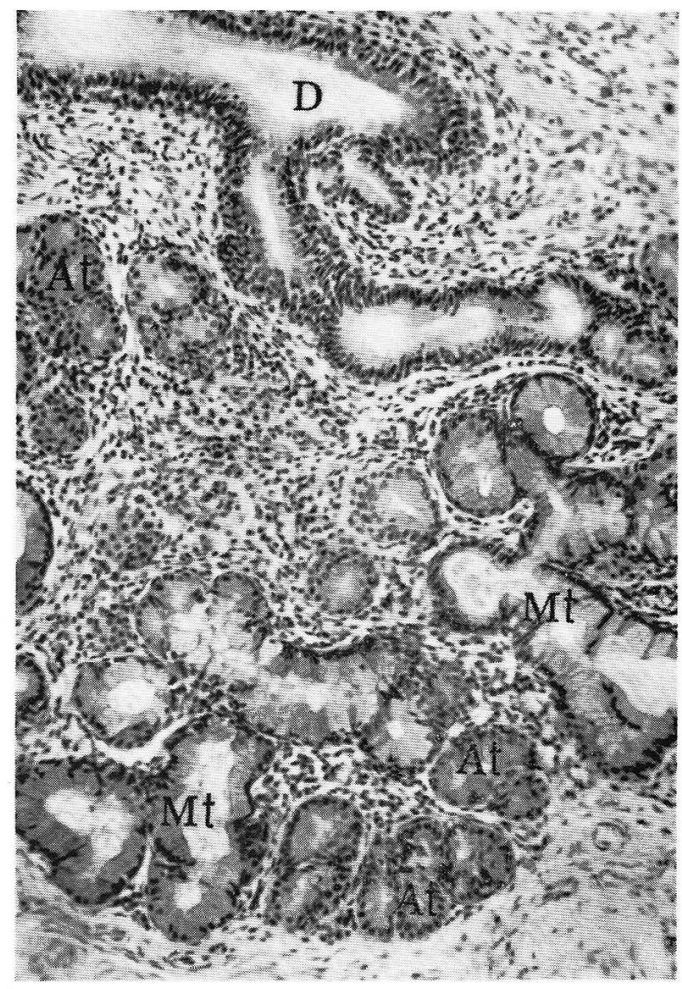

Fig. 7. A tracheal gland in the paries membranaceus. The excretory duct $(D)$ is branched. The mucous glandular tubules $(M t)$ continuous with the excretory duct show complicated ramification, the albuminous glandular tubules (At) are found in the more distal parts. ZENKER-formol, hematoxylin (HANSEN)-eosin. $\times 120$ に見え，漿液頪粒で允満した

細胞に於いても，顆䊀によって核が压排变形することは無く，円形或いは帮円形 を保ち，細胞の基底側に偏して热められる。粘液染色，特に Bauer 氏反応を施し た標本では両種顆粒の鑑別は容易であるが，PAS 箵本では分泌顆粒は画者共深紅 色に浱染し，細胞の位置，顆粒の充洲している場合には核の形態，また顆粒の雀 積状態によって鑑別しなければならない，Bauer 祭本では，粘液顆粒は紅紫色に 濃染するが，漿液顆粒は染色性が弱く，淡紅色に染色され，2 䅖の頪粒は明らか に染別される（図８）。両種顆粒の反応は共に喠液消化试験で変化を受けず，グリ コーゲンによるあのではないととを証明した。

分泌顆粒を持たない休止期の粘液細胞之漿液細胞との識别は困難であるが，そ の分布状態には一定の顺序がある。乙の分存の法剘は人の鼻腺（䍜井 1958）で報 告されているものとほぼ同様である。2 程類の腺細胞が容罗に胃け分けれるよう

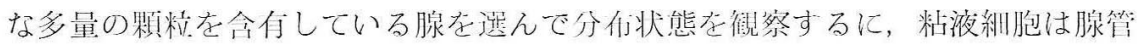




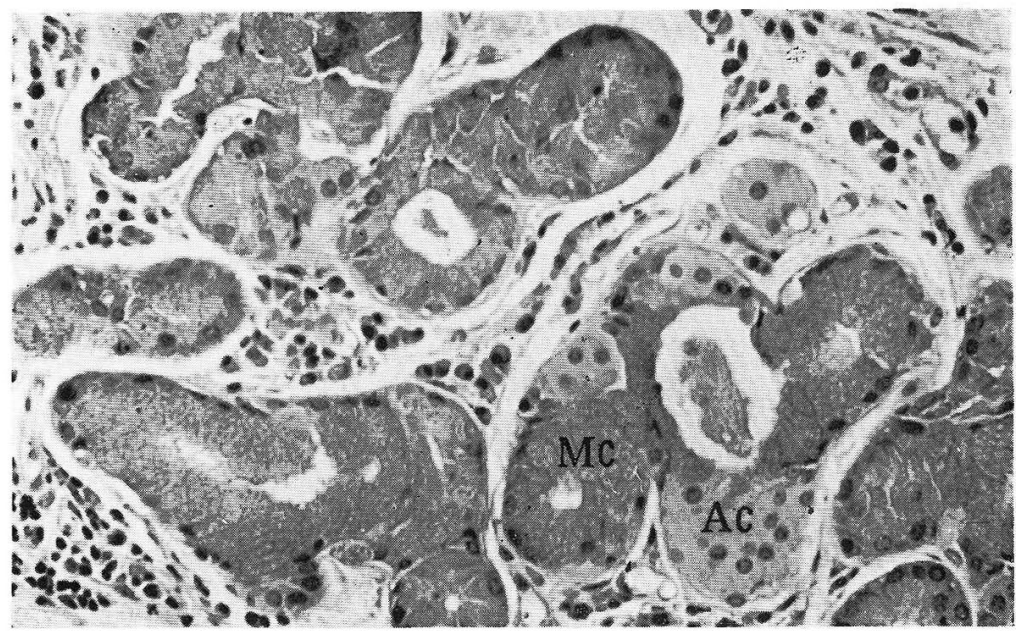

Fig. 8. A portion of the tracheal glandular body. The mucous granules in the mucous glandular cells $(M c)$ are stained deep red-purple (dark), while the albuminous granules in the albuminous glandular cells $(A c)$ poorly (clear). Formol-alcohol, BAUER's reactionhematoxylin (HANSEN). $\times 240$

の分岐の中で導管に直ぐ続いて開口部に近い位置を古め, 漿液紐胞はそれより更 に末梢部に存在する。即ち導管に続いて粘液細胞で朋まれた，太くて内㓐の広い 腺管（粘液管 Schleimrohr）功ある。この主粘液学から数次に亘って分岐し，次第 に細くなる粘液管分枝が出る。この枝から多数の管状や胞状の漿液細胞からなる

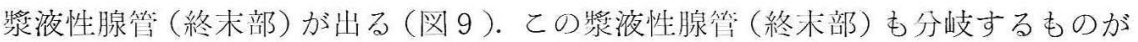

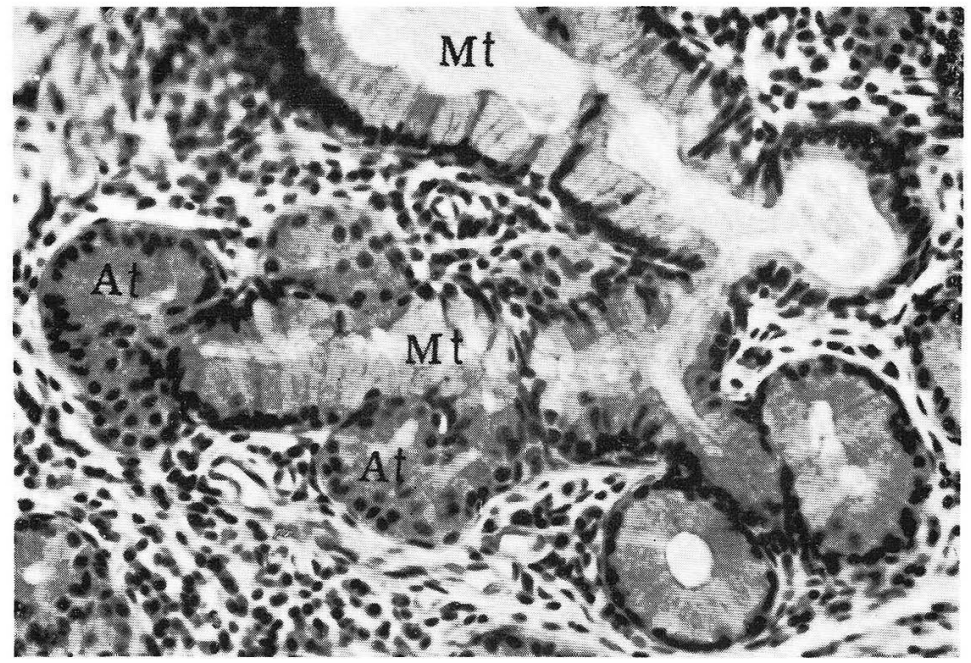

Fig. 9. Ramifications of a mucous tubule (Mt). Albuminous tubules $(A t)$ and acini open to them. ZENKER-formol, hematoxylin (HANSEN)-eosin. $\times 240$ 
ある，時に太い粘液管に漿液性腺管が直接開口することもあり，更に粘液管の末 端或いは壁の粘液細胞の間に，漿液細胞加ら成る種々の大きさと北を示す多数の 半月を認める（図 10)，粘液管は一方で導管に連続し，他方で浆浓性腺管（終末

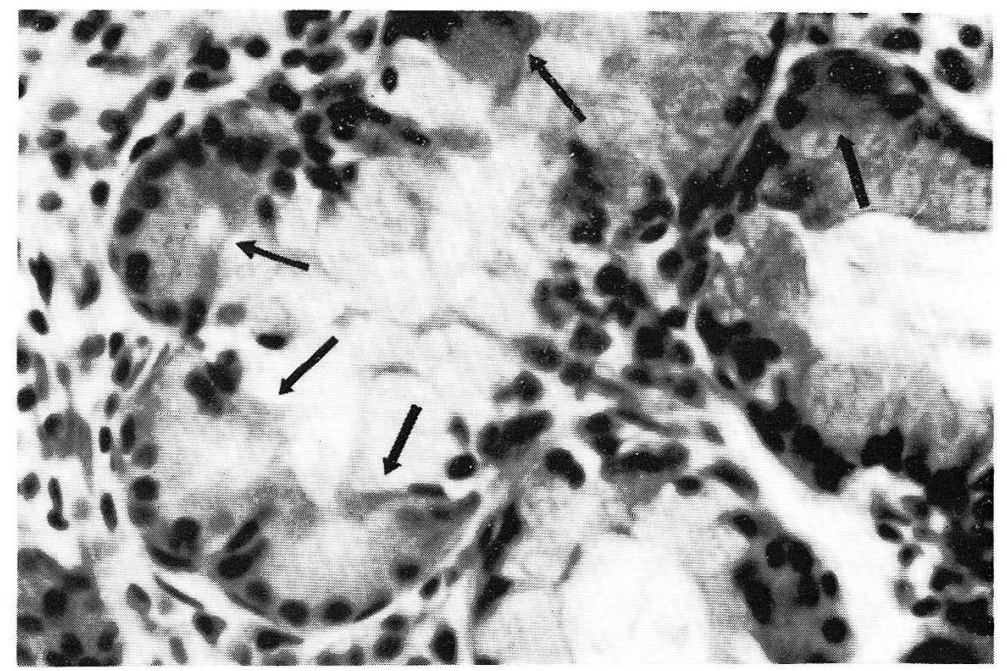

Fig. 10. Many demilunes $(\uparrow)$ of different shapes and sizes are found in the wall of a mucous tubule. The demilunes consist of albuminous cells (dark). ZENKER-formol, hematoxylin (HANSEN)-eosin. $\times 480$

部）及び半月に接続し，乙れ等からの分泌物の奨管の役屯務めている。以上の邚 き 2 種腺細胞の分有の順序が逆になることはなく，㴪管に浆液性腺管が直接開口 したり，半月が出現することはない．この様な腺細胞の規則的な分布状態から分 泌顆粒を持たない細胞の識别む可能となる。漿液練胞の全く見当たらない腺，或 いは全く粘液細胞を欠く腺，すなわち純粘液腺，繾漿液腺は存在しない，人の気 管腺はすべて混合腺である。乙れ等腺管壁には平滑筋線維型の多数の筋上皮細胞

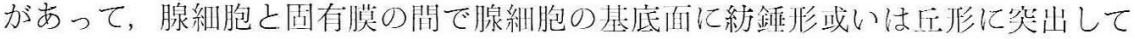
見出される。

e) 気管腺に於る半月.

導管に続く粘液管には漿液性終末部が開口するが，また粘液管の管壁には粘液 細胞に混じて漿液細胞の集団，すなわち半月 (demilune, Halbmond) が多数存在 する。この様な半月は上皮陌山部や茅管壁には出垷しない，粘液管，特に分岐を 繰这して未梢に订い粘液管分枝に多数の半月が見出される。半月には，粘液管壁 K並ぶ数個の浆液細胞から成万小さいものから，大きいものでは胞状に突出して 漿液性終木部に沂い形態をとるものまで，種々の段階が見受けられる。数個の漿 液細胞の群ふら成る簡単な形の半月では，漿液紐胞は基底面が広い円錐形で，扇

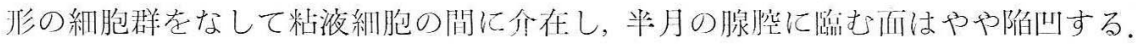

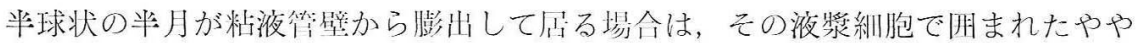


深い陥凹が粘液管腔に開く，半月が大きく球状に近づけば，半月の基底面は粘液 管より外方に突出し，中央の漿液細胞に困まれた陷凹は益々深くなり，更に管状 に近く突出する場合には, 短い漿液性腺管或いは胞状の終末部に近い形態をと る。即ち半月は発育の悪い漿液性腺管或いは終末部と考えられ，更に発育して漿 液性腺管或いは終末部を形成することも想像できる。漿液性腺管と半月とは本質 的に同じ系列に入るもので，両者の間には種々の発育段階にある移行が存在する ようである。

前述の如く, 粘液細胞之漿液細胞は休止期にては見分け難く, 半月もその漿液 細胞と所属する粘液管の粘液細胞との差が判然とせず, 半月の存在が明瞭ではな くなり，混合腺であることが不明確になることがある。しかし半月を持つ粘液管 の粘液細胞が分泌機能休止状態にある場合であ，半月の漿液細胞に漿液性分泌顆 粒が存在し, 独自の分泌機能が行われているのを見ることがある. 即ち半月の分 泌機能は粘液管の粘液細胞の分泌機能或いは分泌週期とは同時性ではなく, 独立 していることを思わしめる。以上の如き半月の形態学的所見から見ると唾液腺に 於ける半月の形成に関する Heidenhain の粘液化説 (Verschleimungstheorie), すな わち半月は介在部上皮細胞の粘液化により圧迫された漿液性終末部で形成される との説は，気管腺には当てはまらない，気管腺に於ける半月は発育の悪い漿液性 終末部に他ならないと考える。

半月にある漿液細胞の微細構造, 分泌顆粒の形成過程などは, 漿液性終末部に 於ける漿液細胞のそれ等と本質的に同じである。半月に於いてあ腺上皮の外側で 固有膜との間に筋上皮細胞を認める点む, 漿液性終末部と全く同じである.

f）気管腺の腺管壁之筋上皮細胞.

粘液管及び漿液性腺管（終末部）は共に腺腔を中心に囲んで最内側に腺細胞が 1 層に並んで腺腔に面して居るが，半月では腺細胞の配列はしばしば複雑で不規 則である。しかし大部分の半月では腺細胞は 1 層に並んで腺腔を形成する陷凹を 囲んで居る、両種腺管壁の腺細胞はその分泌機能の各段階に応じてその高さと大 きさが異なり，分泌顆粒或いは分泌空胞で充満している腺細胞は高くなり，腺管 壁は厚く，相対的に腺挖は狭くなる。併し一般に粘液管の方が漿液性腺管よりも 腺腔が広い，漿液細胞の間には細胞間分泌細管が認められるが，粘液細胞の間に は見られない，腺細胞の外側に腺管の外表面を包む固有膜があり，導管にまで伸 びて，その固有膜に移行する。

固有膜と腺細胞基底面との間に狭まれて筋上皮細胞が認められる。一般に筋上 皮細胞と呼ばれるものには 2 型犬シあり, 汗腺や乳腺に認められる平滑筋線維と同 じ形態構造を示して腺管の長軸の方向に走り, 筋原線維の分化のあるあのと, 唾 液腺その他の腺にて見られる籠細胞型のもので, 突起を出して網状や文字通り籠 状に腺の終末部を包むものである．Fuchs-Wolfring (1898) に依れば気管腺に見ら れるものは籠細胞 (Korbzelle) 型のものである. その後気管腺の筋上皮に関する報 
告は無いが，著者の觀祭ではすべて平滑筋線維型の形態を示すむのばかりで，籠 紐胞型の屯のは涊めら扎なった。即ち平滑筋線維型の筋上皮細胞が腺管の長軸 の力向に一玫して伸び，腺管の横断面では基に横断されて丘状或いは三角形に腺 細胞の基底部へ突出し，核を含んだ部の门が最も広くなる。核は一般に明調，長 惰円形であるが，横断面では小円非に見える，1-2简の核小体を持つ，細胞質 は明るく，細胞の長軸の力向に走る極めて䘗細な原線維本を有する。原線維は 固有膜に沿って走り，敛 hematoxylinであ殆ど染 らず，灰色に明るく見元 る(図11)，筋上皮縕胞は 粘液管，棌流性腺管及び

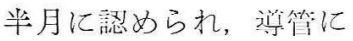
況い部より末梢に沱い部 に於いて分乍は密であ る。併し分们密度は汗腺 に於けるほど密ではな く，散在性である。背管 壁及び開口部の表面上皮 の陹山部の壁には存在し ない，筋上皮細胞の機能 は，收縮により，腺腔内 の分泌物老腺の開口部へ 向加て压出するものと 考えられる。

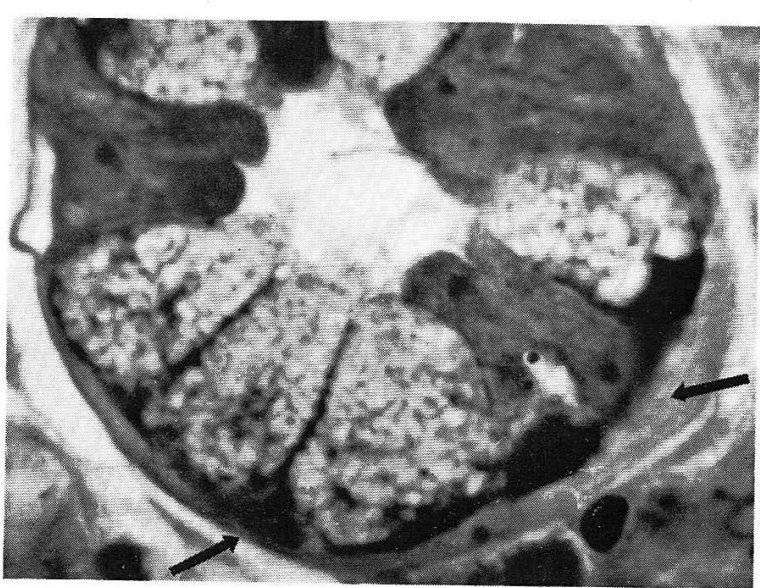

Fig. 11. Mucous cells filled with a large number of mucous granules (clear): secretory granules loaded stage. Their nuclei are compressed to the basal part of cells (dark), and mitochondria are seen between mucous granules. Many albuminous cell groups (dark) are found between the mucous cells, which represent small demilunes. Between grandular cells and the membrana propria, there is a myoepithelial cell of smooth muscle fiber type $(\uparrow)$. LEVI, ironhematoxylin (HEIDENHAIN). $\times 1,080$

\section{B. 腺細胞の細胞学的所見亡分泌像.}

人の気管腺は混合腺であり, 両種腺細胞が細胞質内に分泌顆粒索持ち, 分泌機 能を営みつつある時はその鑑別は容荡であるが，機能休止状態にある場合はその 鑑別は非常に困難である。しかし前に述べた如く，両種腺細胞の分布には一定の 法則があり，粘液細胞は導管に続く粘液管に，漿液細胞は更に未梢の終木部或い は半月に見出される。一般に腺細胞の細胞質内には糸粘体, Golgi 装置, 分泌顆粒 等が証明され，それ等は腺紐胞の分泌活動の時期に応じて変化する。特に細胞内 で座生された分泌物は顆粒を形成し，細胞内に一畤的に貯蔵され，腺腔へ排出さ れる。かかる現象在繰返すことに低って腺細胞には一定の分泌周期が現われる。 腺細胞は分泌周期の各期に応じて, 細胞学的棈造に複雑な变化を見せる。

a) 粓液細胞。

粘液管壁に並ぶ粘液細胞には種々の分泌機能段階にあるものが見られるが，同 一腺でも部位により，また紐胞によって機能の時期は必ずしも等しくない，一般 
に粘液颗粘で充湍している粘液紃胞が多く，機能休小状態或いは分泌顆粘の少な い細胞は少ない。

機能休止期，機能休止期或いは分泌間期の分泌物空虚な粘液細胞は休止期昹液 細胞との鑑別が困難である。休止期粘液細胞は分泌物を充满している細胞と比較 すると細胞の高さはやや低いが，门柱形を保ち，门は狄い。隣接する細胞の腺膑 面の間に閉鎖堤がある。核は円帅ないし政门形で，小さい核小体を持ち，組胞の 中央からやや基底侧に偏して存在する。敛 hematoxylin 染色や azan 染色で核上 部に明るい細管より成る Golgi 装置の除像が認められ, Kolatchev 氏法ではオスミ ウム酸で黑化して，核の上極に损して小さくまとまった簡単な縌或は系球を䚲成 し，活動中の細胞に見られるような大きい疎綿状の据りを示すととは無い（図12）.

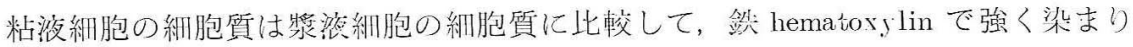

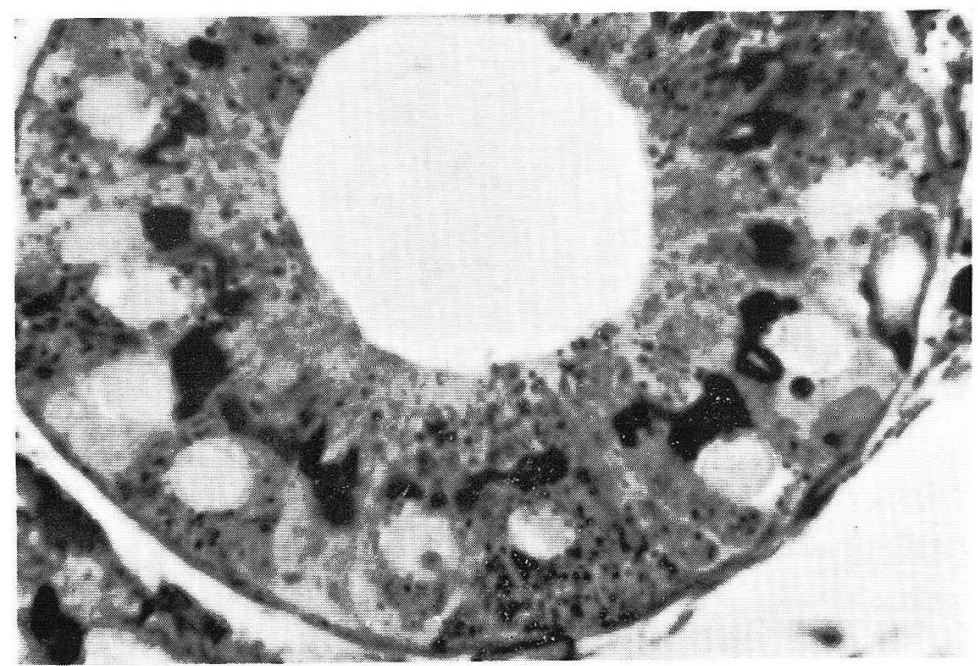

Fig. 12. GOLGI apparatus of the rincous cells in resting phase: cross section of a large mucous tubulc. GOLGI apparatus (blackened) is found as a small network or a small loop in the supranuclear zone of the columnar mucous glandular cells. KOLATCHEV's osnium impregnation method. $\times 1,080$

喑調である。気管腺の川には粘液管の粘液細胞の殆どすべてが休止期にあり，粘 浓顆粒を含まず，細胞も立力形でやや低く，䏽調で，その位置関係から粘液管と 分るような腺が時に热められる。との様な腺では半月や漿液性終木部の識別も容 坚ではない，学者により純漿液腺と見倣された腺はかかるものではないかと考え られる(図 13)。

補充期，粘液顆䊀は核上部の Golgi 野内に出現する。鉄 hematoxylin 染色では 粘液顆粘は染まらずに明るく拔けて罗え，核上部の明細管として見える Golgi 陰 像内に明るい顆粒がたまる結果，明細管の太さが増したように見える，粘液細胞 はPAS 反心で紅色に強染し(図14), Bauer 氏反応でも紅紫色に染色される、Bauer 


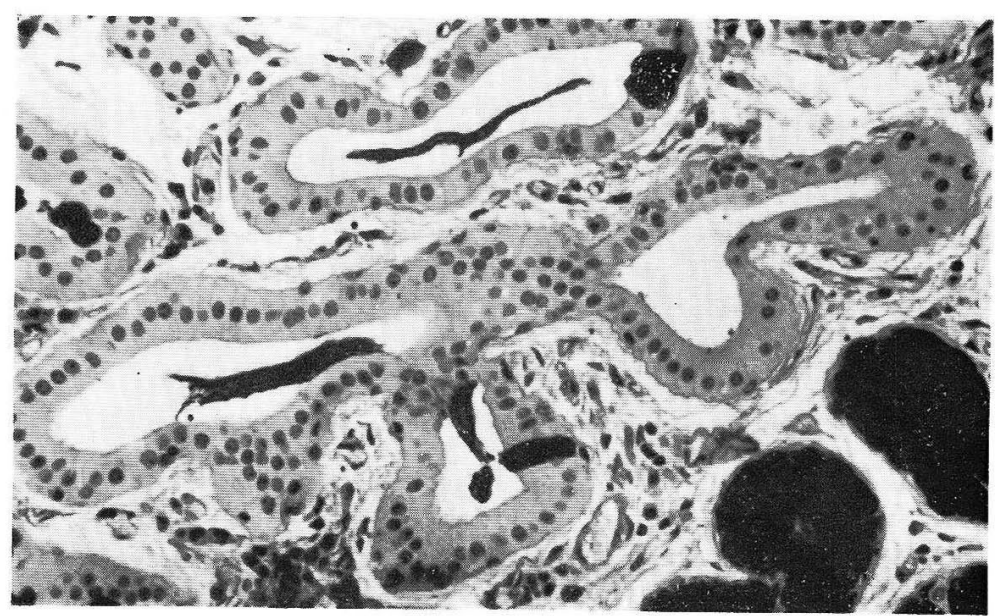

Fig. 13. A tracheal gland composed almost exclusively of resting and empty glandular cells, the mucous and albuminous cells do not contain secretory granules, so that both cell types can not be differentiated from each other. In the under-right corner, there are observed mucous tubules of another gland composed of mucous cells filled with PAS-positive secretory granules (dark). Formol-alcohol, PAS-hematrxylin (HANSEN). $\times 240$

氏反応後に敛 hematoxylin 染 色を施した標本 では敛 hematoxylin で不染の Golgi 野内に紅: 紫色の顆粒が存 在するのが羿め られる。核上部 の Golgi 装置内 に出現し, 此处 に集積した颗粒。 は次第に絒胞の 先端部に移行 し, 細胞少端部 に粘液頪粒の集 積を見るように

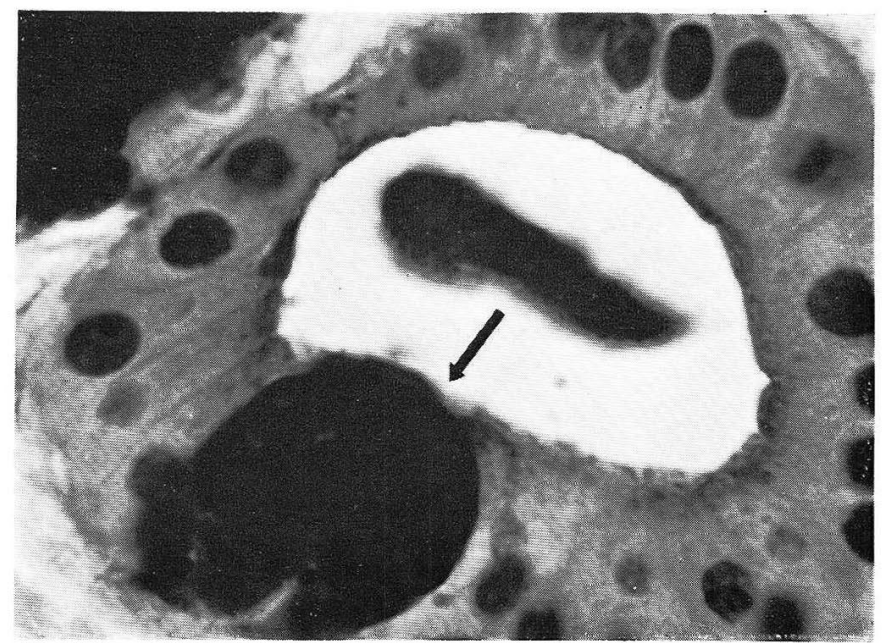

Fig. 14. Cross section of a large mucous tubule lined by columnar mucous glandular cells in restitution stage. Small PAS-positive mucous secretory granules (dark) are elaborated in the supranuclear GOLGI-zone, move to the apical part and make a small accumulation there. Two large bulky mucous cells filled with PAS-positive mucous granules $(\uparrow)$ in the glanduなる。乙心時核 lar epithelium. PAS-hematoxylin (HANSEN) saliva-digestion test. $\times 1,080$ 上部の細胞先端部の粘液顆粒の集㯒が明るく見えるため。2者の間に暗調な原形 質㞗が認められる(図 15)。乙れは横地（1951）が十二指腸腺腺紲胞で記載した中 


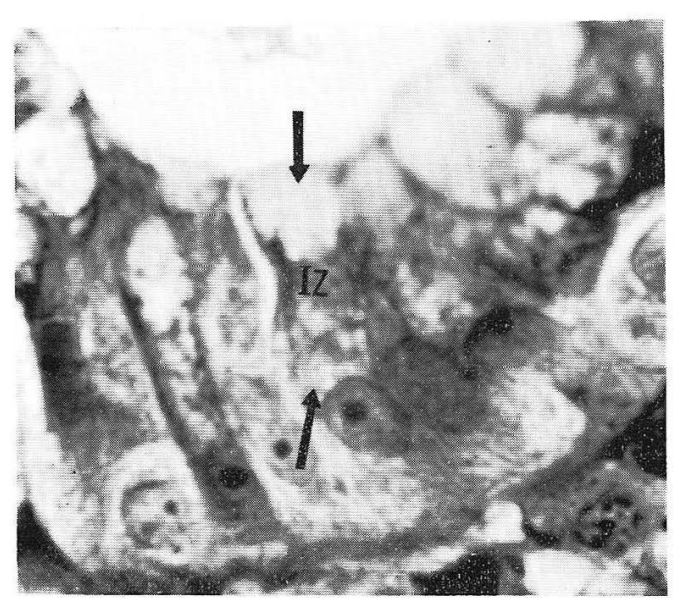

Fig. 15. Mucous cells in restitution phase. Between the accumulation of mucous granules in the apical part of cell $(\uparrow)$ and in the GOLGI field $(\uparrow)$, there remains an intermediate dark plasm zone $(T z)$. Many filamentous or rodshaped mitochondria are seen in the basal cytoplasm.

LEVI, iron-hematoxylin (HEIDENHAIN). $\times 1,080$
間愔兴に相当する，顆粒は次第 にその量を增し絸胞も高く大さ くなる。核はまだ円帅ないし栴 円形を保ち, 明るく, 紼胞のや や基底側飞寄って位置し，压迫 像や扁平化し浱縮されたような 像は見られない，多数の短い系 状或いは诨状の系䊀体が細胞の 基底部及び中間带に分布し，集 積した顆粘の間にも多数存在す るのが見られる(図15)。顆精が 增量しても系粒体の数が咸少す るような所見はない，Golgi 装 置は核上部上り細胞少端部に向 加て搪大し，その網目も疎に なる。Golgi 網は中間暗㮐运搪 核

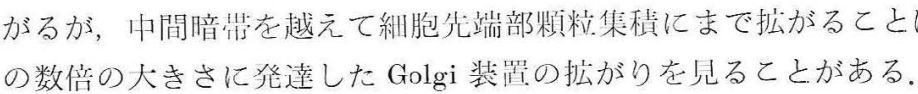

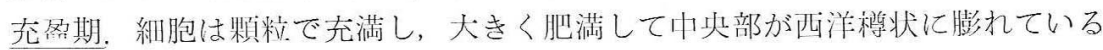
像をしばしば見る。細胞質は基底部に薄く压迫され，中間暗带も嗾ざ見られず， 充渾した顆粒のために 練胞は明るくみ元，基 底部の薄い細胞質のみ が暗調走す、PAS 反 応, Bauer氏反応では紐 胞の殆ど全体が粘液顆 粒のため紅色に染色さ れ（図 14），核は基底 部に強く压迫さ机変形 し, 扁平化或活緗胞の 一隅に三你形に押しや られ(図11), 多くは濃 縮して暗く, 核小休等 の棈造の末だやや明ら かなあのから，全く不 明なものがある。系精 体は㛙系状或いは小桿

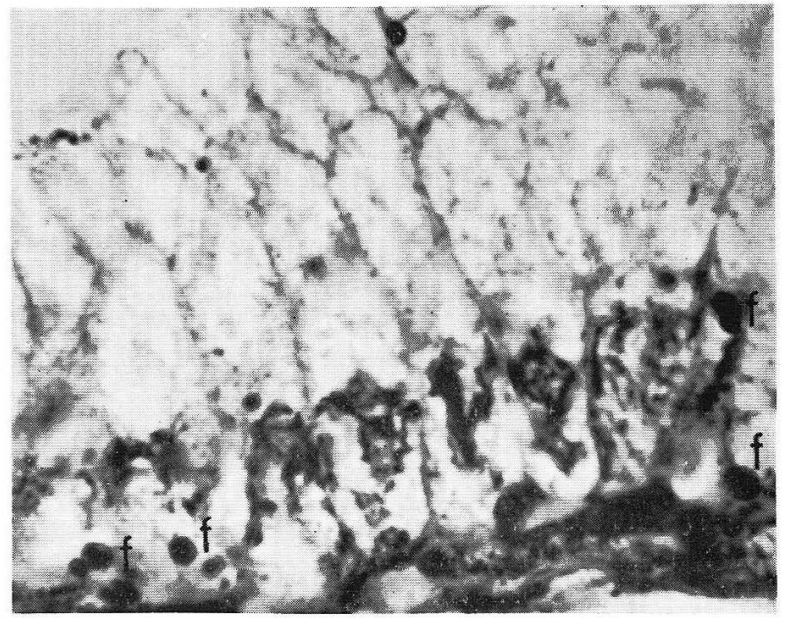

Fig. 16. GOLGI apparatus of mucous cells filled extremely with mucous granules (clear): loaded phase. GOLGI networks are situated in the intermediate plasm zone, and contain mucous granules (clear) in their meshes. $f$ fat droplet (blackened). KOLATCHEV's osmium impregnation method. $\times 1,080$ 
状で, 粘液顆粘の間に多数存在するのが認められる（汶 11）. Golgi 装置の陰像は 不明となる，Kolatchev 氏法に依り黑化検出すれば Golgi 装置は中閒暗临に相当す る部分に複雑な網を形成し，網眼の中に明るい粘液顆粒を抱く（図 16）. 併し先端 部の粘液颗粒間へは広がらない。しばしば多数の小空胞を含む有胞性脂肪榈を認 める細胞がある。

排出期. 粘液顆粒により肥洏していた細胞はその顆䊀を排出することにより再 び細くなる，粘液顆粒で充渾した粘液細胞の先端部が腺腔へ膨隆し，或いは粘液 顆粒を含む突起が腺腔へ突出する像が時に钼察されたが，くびれて腺腔へ脱落す るアポクリン分泌を思わせるような像は認められなかった。この时期でも系粒体 は顆粒間に多数存在する. Golgi 装置は次第に核に向かって管縮し小さくなる。

粘液細胞の分泌機能状態を時期を追って観察するに, 系粒体は顆粒が産生され 蓄積されてす, 顆粒間に多数存在し，顆粒の増量と共に減少しないように思われ る。また Golgi 装置は休止期には密網状で核上部に小さくまとまった小体を作る が，補充期に入り，その中に粘液顆粒が出現すると共に次第に大きく広がって， 核上部から中間喑带にまで拡大した疎網を作り，顆粒は核上部から次第に細胞先 端部へ移行し蓄積する。顆粒が増加し，細胞が大きさを増せば Golgi 装置も更に その絧を広げる，充盈期には大きな変化を示さないが，排出期に入り，稹粒の排 出が行われ細胞が細くなると 共に Golgi 装置も篓綟する。 この様な粘液細胞に於ける系 粒体，Golgi 装置及び粘液顆 粒の变化から考察するに，粘 液細胞に於いては顆粒の形成 に関与するのは Golgi 装置で あり, 糸粒体は変化を示さず, 顆粒形成には直接関係しない あの之考える。即古顆粒は Golgi 装置内で産生されるも のと思われる。

しばしばオスミウム酸で黒 化するリポイド頪粒(脂肪㵜) を認めた。多くは核上部に存 在し, Golgi 野内または Golgi

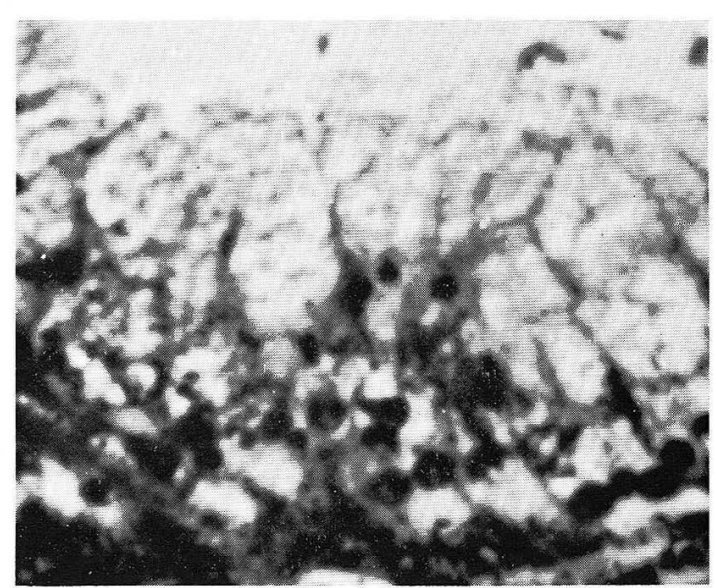

Fig. 17. Many fat droplets (blackened) are found mainly in the GOLGI-zone of the mucous cells filled with mucous granules (clear). Some of them contain small vacuoles (mono-or polyvesicular). In these cells the development of GOLGI apparatns is depressed. KOLATCHEV's osmium impregnation method. $\times 1,080$

野に近接して認められるが，時に核上部のみならず核問囲から中問暗带にまで 分布することがある。大きいものでは中に 1 ないし数䦓の小空胞を含み，多胞性 に見える（図17）。 
b) 獎液細胞。

漿液細胞は漿液性腺管（終末部）及び半月を形成するが，よ゙ちらの漿液細胞む 全く同じで，分泌機能の各段階に応じた細胞学的変化にも差異は無い．腺細胞は 円柱形或いは円錐形で，腺腔面の間には䦥鎖堤を認め，また隣揬紐胞閒には細胞 間分泌細管が見えることがある。

機能休止期。休止期の漿液細胞は高い円柱状をなし，核は円形或いは梆円形で 細胞の中央かやや基底側に寄って存在する。 Golgi 装置は休止期の粘液細胞より

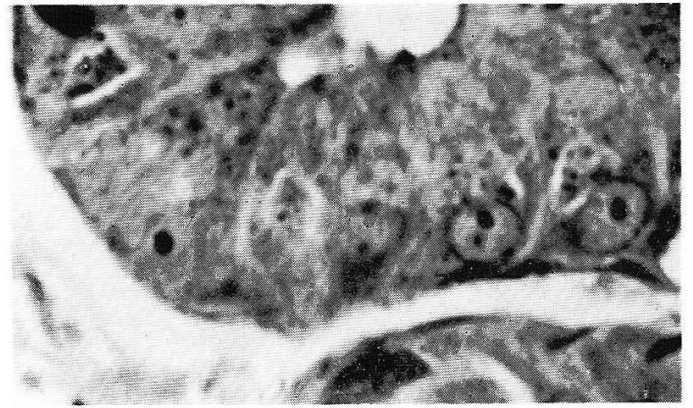

Fig. 18. Albuminous cells in resting phase. GOLGI-negatives are found in the supranuclear region as networks or rings of clear canaliculi, in which already appear a few secretory granules (dark). LEVI, iron-hematoxylin (HEIDENHAIN). $\times 1,(080$ よく発達し，まとまった閉鎖 された絧を核上部に作ること がその陰像から明らかである (図 18).

補充期，分泌颗粒が産生さ 机 Golgi 陰像内に出現して来 る。核上部に在る Golgi 装置 はなお閉鎖された大きい網を 形成する (Golgi 野), 産生さ れた漿液顆粒は eosin，鉄 hematoxylin 飞染まり, Kull 氏法 で anilinf uchsin aurantia に赤 染する。Azan 染色では糸粒体 と共に一部の頪粒はazocarmin に赤染し，大部分の顆粒は anilin 青で青色に染色され る。漿䍇颗粒はPAS 反応で は紅色に浱染するが, Bauer 氏反応では淡紅色に染まり， 明汃に粘渡頪粒とは区分され る。顆粒の産生と共に Golgi 装置は次第に大きく広がり， 粘液細胞に見られたものより 大きく複㮅な絧定示し，この 中に含まれる分泌顆粒も增加 する（図 19），Kolatchev 氏法 により黒化した Golgi 装置の 陽像を見てす，時に顆粒が Golgi 装置の索條に沿って珠 数状に見えることがある，分

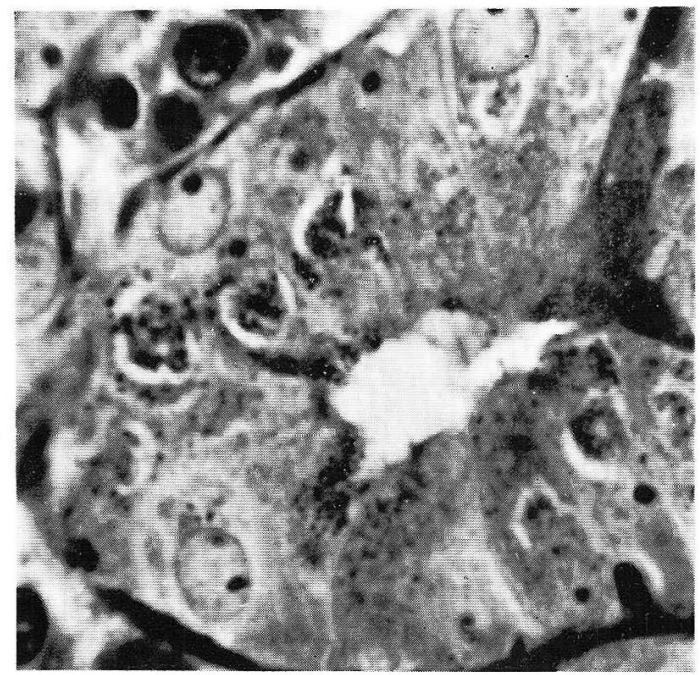

Fig. 19. Albuminous cells in restitution phase. A large number of secretory granules (dark) are elaborated in the GOLGI-negatives (clear canaliculi) and stored in the apical part of the cells. LEVI, iron-hematoxylin (HEIDENHAIN). $\times 1,080$ 
泌顆粒は次第に細胞少端部に移行して蓄積される。しかし粘液紃胞に見る程縕胞 先端部と核上部の頪粒集樍部が明膫に分れて而者間に中間蓝が見られるようなこ とはない，糸粒体には可成り長い系状のむの屯見られる。一般に粘液細胞に見ら れたものより長い系粒体が多く，主として核周囲及び基底部に涊められ，大体細 胞の長軸のう向と一致して走るとはいえ，可成り不規則な走行を見せるものもあ る。時に顆䊀間に存在するのを 見ることもあるが，顆粒の充澫 した部分には見出し難い。細胞 先端部に顆粒が集積すれば，糸 粒体は基底部及び核周团のみに 認めら机るようになる。細胞は 次第に大きさを増し，核は円形 ないし楕円形を保ち細胞の中央 部加やや基底寄りに存在す b.

充盈期. 分泌顆粒は更に増加 して細胞は多量の顆粒で充淽し 肥大する、核は蓄積された顆粒 に压されて基底部に偏在するの を胃ることがあるが，粈液細胞 の充盈期に見られるように压迫 されて強く変形したり浱編する ことはない(図 20，21）。乙の事

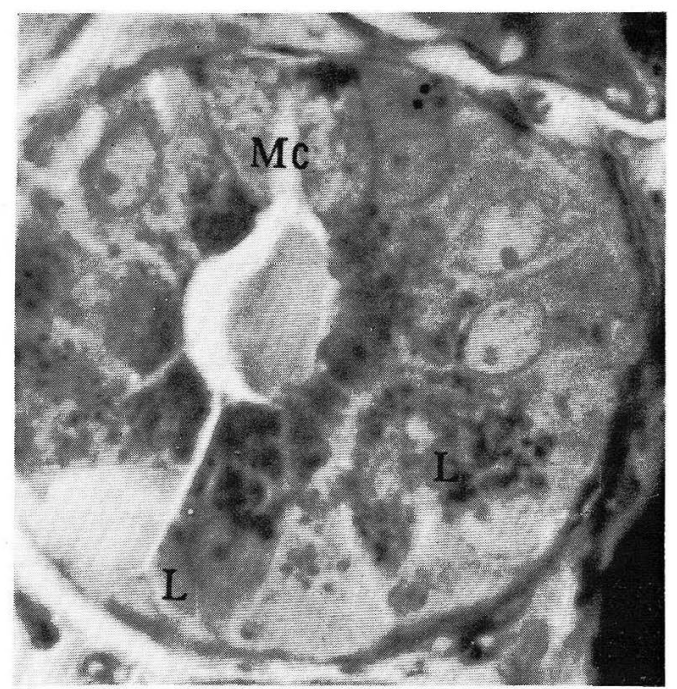

Fig. 20. A cross section of a albuminous acinus. Albuminous glandular cells are in restitution phase and in secretory granules (dark)-loaded phase (L). The nuclei of albuminous cells are all round in shape and do not fall in deformation and pycnosis. $M c$ mucous cell. LEVI, azan. $\times 1,080$

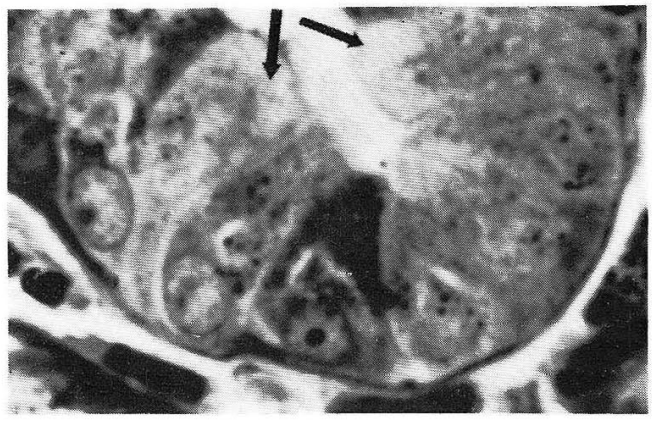

Fig. 21. Albuminous cells loaded with secretory granules (dark), the GOLGI-negatives (clear canaliculi) are found in the supranuclear zone. The nuclei are driven towards the basal end of the cells but never deformated. Secretory granules accumulated in the apical part turn into the secretory vacuoles $(\uparrow)$. LEVI, iron-hematoxylin (HEIDENHAIN). $\times 1,080$
実は粘液細胞との形態学上の大 きな差の1つである。顆粒は次 第に空胞化して分泌空胞となり (図 21，22)，しばしば分泌空胞 在充渾す万突起が腺腔へ向か。 て乫出する。 Golgi 装置は極め てよく発達し, 複雑な網状をな し，核上部汃ら広く細胞先端部 に向かって拡がるが, 分泌空胞 の満ちた上記の突起内までは広 がらない(図22)。糸粒体は核の 周辺部と細胞基底部に僅かに認 められるのみである。顆粒は細 胞の殆ど全体に旦って充満して 


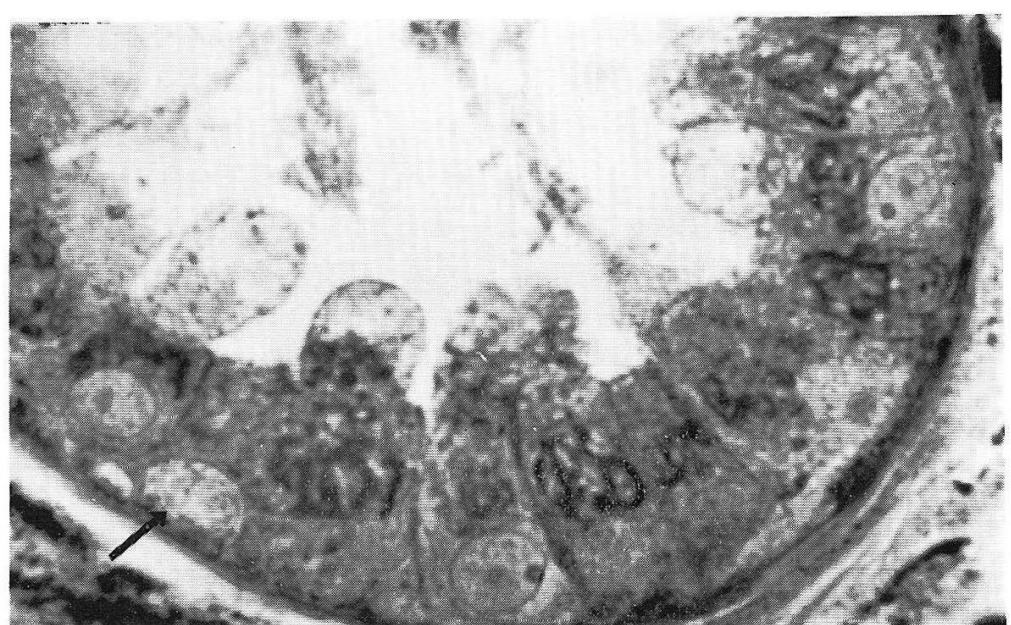

Fig. 22. Picture of apocrine secretion of albuminous cells. Many apocrine projections filled with secretory vacuoles are protruded into the secretory cavity. GOLGI apparatus makes a complicated network extending from the supranuclear zone to the apical part. Cross section of a myoepithelial cell $(\uparrow)$ is found between the glandular cell and the membrana propria. KULATCHEV, KULL. $\times 1,080$

来るが，細胞少端部のあのから次第に空胞化する（図 21），分泌空胞の大ささは顆 粒と略等しく，互いに融合して大きな空胞を帅成するととはなく，䋽胞質内に充 満し，紐胞質は泡沫状に見える。

排出期．空胞化した顆粒は遂には腺腔内へ排出される。分泌空胞を充佩した細 胞突起は次第に大きく腺腔に笑出し，乙の突起の増大と共に空胞は細胞内加突 起へと移行して，突起は細胞白体よりあ大きくなるてとあある。更に突起には縊 れが生じ，腺坨へ離断してアポクリン分泌を行なう像をしばしば見受ける。隣接 する多数の漿液細胞が殆ど同機能時期に在る場合, 多数の乳頭状の突起が膨出し て並び，旺盛なアポクリン分泌像を示す。分泌空胞が分泌され，排出し終わった 紐胞は周囲の細胞に圧迫され，細くなり，細胞全体はやや濃縮して鉄 hematoxylin 染色で浱染し，所謂小桿細胞様になる。核もやや長い楕円形となり，軽度に濃䌐 する。原形質が唉染するため細胞内の微紐構造はあまり明暸ではない.

前述の如く分泌機能状態の変化と共にGolgi 装置に屯変化が見られ, 分泌顆粒 玥成に与かる如く思われるが，系精体の分泌顆粒形成との関係は明らかではない. 鼻腺の漿液細胞に於いて観察されたような系粒体の一部に肥厚部が生じてそれが 離断されて分泌頪粒となるというほどの明確な所見は認められなかった（岩井 1958).むしろ Golgi 装置の機能状態に応じた版態的变化は粘液細胞に於ける場 合と殆ど同じで，また補充期に顆粒が先ず Golgi 除像内に出現することからも， 分泌顆粒はGolgi 装犆内で産生されると考えられる。

漿液紼胞にも時に主に核楇四に，特に㤥上部 Golgi 野或いはそれに接した部位。 
にオスミウム酸で黒化するリポイド顆粒 (脂肪滴)を偲めることがある。やや大き いものは内部に1一数涸の小空胞考含み, 多胞性に見えるこしがある。洔に坒胞化 しつつある浆液性分泌粘粒の間にまで分 们することもあるが, 粘液細胞と同様

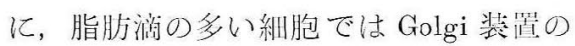
発育が悪いようである(図23).

\section{III. 総括と考察.}

\section{A. 気管腺の発生亡気管腺の数.}

本砸少にて材料しして使用した父管樌 本に㸡児の例がないので, 発生に関してて は何ら諭すべき所見在持たない们え，文 能的考察にとどめる。気管自休の発生過 程は，森 (1952) に依れば,苝ず前腸の咽 頭部腹壁に生じた気管续頭原基が膨隆 し, 尾側方向に问功て伸び, 中に咽䫓 汇通ずる喉頭気管管在作るという。この

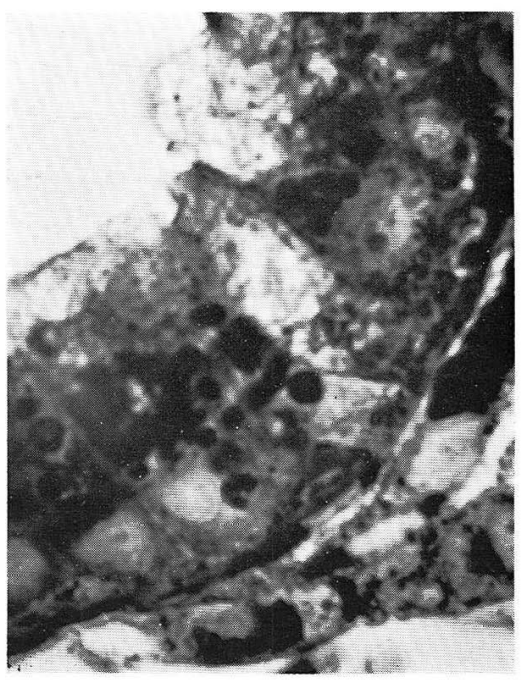

Fig. 23. Many fat droplets (blackened) found in the supranuclear region of the albuminous cells filled with secretory granules and vacuoles. Some of them contain small vacuoles (mono-or polyvesicular). In these cells the well developed GOLGI networks are scarcely found. KOLATCHEV, KULL. $\times 1,080$

盲管が気管の原基であり，乙㞦気管腺の出現するのは胎生 4 月としている。古 くKanthack (1890) は喉顛腺が胎生 3 月に生ずると述べて居るが, 気管腺の発生 に就いては明らかな記䡠は無い，安滕(1960）に依れば，気管腺の原基は胎生 3 月になって膜性壁の筋層の外側に始めて認められるが, 未だ小さく, 明膫な腺開 口部は見られないという。. 4 月目に到り腺開几部が証められ，5月になると腺体の 増加が著明になり，大型の腺も出現し，数個集まって群を形成し，また軟管壁に 屯出現し，軟骨問部にも大きい腺が現われる。 6 月には腺の大部分は出現し，8月 の人胎児に於いては粘液細胞と漿液細胞の区別が明膫に見られ，混合腺を成すの が認められると述べている。すなわち3月に出现し，8月に到机ば大体の形態が 出来上るあののようである，腺の開川部は 4 月胎児で桬められ，奨管は固有層を 直走して粘膜上皮に達し，上皮を火口状に買いて開口し，阰に上皮陹山の比成 がなされつつあるものと考えられる記載を見る. Thurlbeck, Benjamin とReid （1961）は腺芽というべきすのを胎生 12 週目に見出し，覱に紐胞内に空胞を認め, 18 週目には小葉の形成を热めたと䛉述している。しかし彼等は人の気管腺を粘液 腺のみと考えているようで，粘液細狍のみを取上げ，漿液紏胞に関しては全く触 れていない.

父管に存在する腺の総数に関して, Thurlbeck, Benjamin とReid (1961) は, 粘 液腺のみという考え方ではあるが，人胎巟の気管で全腺数在数える公式在考案し， 
それによって胎児の気管腺の総数を数えている．個人差はあるが，出生時には男 子 4,000-6, 000, 女子は 3, 500-5, 200 個. 男子の方が女子より多いのは気管の 大きさの男女差によるものではなく，腺の分布密度の差によるものであるという. 更に胎生 16-17 週頃までは気管の頭側の方が尾側よりあ腺の数がやや多いと記 載されている. Emery と Mithal (1961) に依れば，腺の総数は早産児に於いては 正常児の $200 \%$ に及゙，また年長児では腺数に個人差は少なくなると述べている。 著者はすべての材料を $3-4 \mu$ の厚さの切片として使用したため, 腺の総数を数 えることは出来なかった。

\section{B. 気管線の一般的形態.}

1. 一般的形態に関しての歴史的考察.

人の気管粘膜上皮に関しては日置 (1942) の詳細な細胞学的研究があり, 家鬼 や鼠ではその電子顕微鏡的研究む報告されている（Rhodin とDalhamn 1959, 吉 岡 1960）が，気管腺に関する文献は少なく，記述む簡単である. Tarchetti (1871) の犬と人の気管に於いて, 粘液腺と並んで細胞質性腺細胞 (protoplasmatische Drüsenzellen）及び Giannuzzi 氏半月を認めたという記載が最初のあのである。乙 の細胞質性腺細胞が漿液細胞であることは明らかではないし, 機能休止期の細胞 という概念は当時未だ無かったようである。しかし彼も分泌顆粒を含まぬ腺細胞 の存在は認めたわけである。Frankenhäuser (1879) は人の気管腺の大部分は粘膜 下組織内に在り，一部小腺が粘膜内に存在することもあり，大腺は軟骨間腔に 3 —5 列の層をなしていると記している。乙れよりさきA. Heidenhain (1870) は鼻 腺にて粘液腺と漿液腺の 2 種類の腺を認めて居り, R. Heidenhain (1883) は気管 腺之喉頭腺は極めて類似し，共に粘液腺であると述べている. 1882 年 Waller と Björkman は成人気管及び犬, 猫, 恖の気管を研究し, 腺葉には多数の粘液腺とそ れよりやや少い漿液腺の 2 様の形態があることを認めた. Tarchetti は漿液細胞を 証明して居ないので, Waller と Björkmanの記載が人の気管腺を混合腺とした最 初のものと思われる。併し気管腺を当時まだ混合腺と考えない学者あ少なくなく， Przewoski (1898) は人の気管憩室の研究で, 気管腺は粘液腺であると考えた。 1898 年 Sophie Fuchs-Wolfring は犬, 猫, 兔, 鼠, 人に就いて, 気管腺は混合腺であ ると明記し, 分泌細管 (Golgi 陰像のととと思われる) は漿液細胞のみに存在し, 粘液細胞には存在しないと記述, 更に半月（Randzellenkomplex と表現）と多数 の籠細胞を証明したと述べている。乙れは当時としては可成り詳細な研究で，そ の後気管腺に就いてはてれ以上の記載は殆ど見当たらない. Denker-Kahler の Handbuch 内の Schumacher (1925) の記載や, Möllendorff の Handbuch 内の Heiss (1936) の記載む, 共に Frankenhäuser や Fuchs-Wolfring の転載のみで何ら新所 見やそれ以上の詳細な知見の記録はなく, Rauber-Kopsch (1955) の記載も又同様 である，森 (1952) は気管壁の位置により腺体の形に多少の差のあることを認め, 
軟骨部では小さく, 扁平で, 量すすくなく, 膜性壁では大きく量も多いとし, 胞状管 状腺で, 終末部には漿液腺あり, 粘液腺あり, 混合腺ありと記して居る. Bargmann （1959）は気管腺は導管が上皮の漏斗へ開口する混合腺であると述べ, 橋本 (1960) は純粘液腺と混合腺の 2 種類があると考えている. Maximow と Bloom (1960) は 気管腺は主に固有層に存在し, 後壁の屯ののみ筋層まで広がっていると述べ, 混 合腺であるとし, Ham と Leeson (1961) は腺の大部分は粘膜下層に, 1 部は固有層 に存在し, 多数の粘液腺と少数の漿液腺加ら成ると考えている. 以上主要な研究論 文, Handbuch, 教科書の記載を参照したが, てれ以上の記述を見出すことは出来な かった。気管腺の今日までの研究や知見が如何に貪弱であったかが判る。まして 腺細胞の細胞学的検討や分泌像についての検索は行われて居ない. また導管や腺 管壁の構造に就いても全く記載を見ない，著者の所見からは軟琴部の腺といえど 屯必ずしあ小型のもののみではなく, 腺の形態も単分岐管状胞状腺, 或いは複分岐 管状胞状腺で, 純粘液腺或いは純漿液腺は無く, すべて混合腺であると結論する.

2. 腺の広がり方.

腺の広がり方は気管壁の部位により異なり，軟骨の存在，すなわち気管軟骨が あるために生ずる粘膜の厚さの差と密接な関係を有して居る，鼻腺（岩井 1958） に於ける如き導管のある大腺, 導管のない小腺のような差異は無い. 気管腺はす べて導管を持つ. 膜性壁では腺は表面と垂直或いはやや斜めの方向に伸びて粘膜 下組織のみならず，平滑筋層内に，更に筋層をてえて外膜に迄拡大するむのむ珍 らしくない. 大型の腺は一般に腺体が深く広がって居る。既存の文献には膜性壁 に大腺, 軟骨部に小腺が多いとのみ記されて居るが, 腺の広がり方に関して記載 されたものは見当らない，軟骨部では粘膜下層が薄いために腺体はその薄い層内 で広がらざるをえない，表面上皮陥凹に開口した導管は粘膜下層で表面と平行の 方向に屈折し，その先端で腺体は平面的に広がる。軟骨間部に於いては上下軟骨 間に梁く垂直或いは斜めに腺体が伸びて広がるが。輸状䩲带を貫いて外膜にまで 広がるあのはない，腺の広がり方は存在する部位に依る差を認めることは出来る が. 気管の軸の方向とは無関係である。

3. 腺の開口部.

気管腺には上述の如く導管を持たない腺はなく（上皮内腺を除く）, すべて腺管 に続いて導管があり，導管は管状或いは漏斗状の上皮陥山の底に開口する。導管 が直接上皮を貫通して粘膜表面に開口する腺は見られない. 安藤（1960）は既に 胎生 4 月に粘膜上皮に火口状の陥凹を認めたが，乙の上皮陥凹と導管上皮との差， 及び両者の接続部位については述べて居ない．上皮陷凹には浅い火口状のあのか ら深い管状のものまであり，管状のあのでは上皮陷凹自体が既に簡単な分岐を示 していることがある。骝凹部を覆う上皮は表面上皮と同じ多列繊毛上皮で。繊毛 は送られて来た分泌物の排出に役立つものと考えられる。筋上皮細胞は認められ ない．乙の部には表面上皮之同様に厚い硝子様の基底膜が認められ（渡辺 1956）, 
基底膜がなく，無繊毛の 2 列上皮を持つ導管上皮との境界は明瞭である.

4. 導管.

気管腺の導管に関する詳しい報告はない，岩井 (1958) 鈴木 (1961) は鼻腺の導 管は決して分岐せず，従って鼻腺は単腺であると述べ，横地 (1954) は人の食道腺 で導管の分岐を認めた，著者は気管腺の導管は分岐しないあのが多いが，簡単な 分岐を示すものも稀れではないととを知った，換言すれば，人の気管腺は多くは 単腺であるが，複腺も可成りある，導管は腺体から種々の彎曲を示しつつ伸び, その方向も膜性壁では深部より筋層を貫いて垂直或いはやや斜めに，軟骨部では 表面と平行して走り，それぞれ上皮限山の底に開口する。導管は一般に上皮陥山 より内腔は広く，時に囊状に拡張した部も認められるが，鼻腺（岩井 1958）に見 られたような開口部で縊れを示すととは無く，広い管腔は開口部に近づくにつれ て少しずつ細くなり，上皮陥凹腔の広さに移行する，同じ気道の腺でも鼻腺に於 いては線条部が確認されているが（岩井 1958，鈴木 1961），著者の 25 例の人気管 標本には線条部を有する腺は認められなかった。

気管腺導管壁は 2 列上皮からなり，鼻腺の如く開口部への移行部で単層上皮之 なるような所見（鈴木 1961）は見られない，管腔を囲む円柱上皮細胞の核は楕円 形か長楕円形で, 細胞のやや基底部によって存在し, 相接した円柱細胞の遊離表 面間には閉鎖堤を認める。細胞の先端部に沂く PAS 反応陽性物質が種々の量に 認められ，唾液消化耐性であり，グリコーゲンではない，この PAS 反応陽性物質 が分泌顆粒の集積か否か, 即ち導管円柱上皮細胞に分泌機能があるか無いかは, この像のみでは不明であるが，円柱細胞の Golgi 陰像は核上部に簡単な彎曲を示 す明細管として認められ，腺細胞程発達しては居らず，変化に之しく, Golgi 装置 内に PAS 陽性顆粒の出現も認められず，細胞内に顆粒充満像も見られ好等の所 見から，円柱上皮細胞の分泌機能を断定することは困難である.

5. 腺管の形と腺細胞の分布及び平月.

人の気管腺の腺管の形態に就いては古来記載が無く, 森 (1952）の記述に始め て胞状管状腺との報告を見る。一般に腺の形態は分泌部の形態により管状腺, 胞 状腺, 及び両者の合併した管状胞状腺に分けられ，腺管の分岐の有無により分岐 腺之非分岐腺に，更に導管の分岐の有無により複腺と単腺に分類する．著者の観 察によれば，人の気管腺の導管には分岐しないもの（単腺）が多いが，少数の簡 単な一次的分岐を示すもの（複腺）も認められる。乙の分岐は膜性壁の腺にも軟 骨部の腺にも認められた，導管に続く分泌部は高い円柱状の粘液細胞からなる管 状の粘液管で, 数次に亘って複雑に分岐して次第に細い管となって末梢に到る. その先端には漿液性腺管（終末部）が管状か胞状をなして連らなり更に分岐を示 す。粘液管の走行中にはしばしば漿液性腺管が開口し，また所々に多数の半月を 見る，以上のことから，人の気管腺は多くは単分岐管状胞状腺で，1 部は複分岐 管状胞状腺である。 
気管腺については最近であ粘液腺と考えている学者も居るようであるが，一般 に混合腺説がとられるようになり，著者も混合腺であることを証明した，混合腺 とする報告でも，大部分が粘液細胞でその間に少数の漿液細胞があるという記述 が多いが，著者の材料に於いては 2 種類の腺細胞の間に大きな数量的差異は見ら れず, 漿液細胞も粘液細胞と同様に多数存在するのを認めた。 2 種類の腺細胞に 関しては M. Heidenhain（1920）の「粘液細胞は漿液細胞の粘液性変態である」と いう説が一時かなり広く信ぜられ，気管腺に関しては殆ど唯一の詳細な研究であ ると思われる Fuchs-Wolfring (1898) の報告に於ても「純粘液細胞から純漿液細 胞までの間の種々の機能段階にある細胞を見る」と表現されている，ての考え方 は長期に亘って支持されたようであるが，今日ではそれぞれ分化した別個の独立 した種類の腺細胞であるという考え方が一般に信ぜられて居る。

腺細胞の分布状態を見るとき，粘液細胞と漿液細胞の区別が明確でなければな らない，今世紀初期までは上記のように2 者の根本的区別が認められて居らず, その移行が考えられたため, 分布については殆ど記載されていない. 本研究にお いても活動状態にある細胞では分泌顆粒の性質その他によって両種腺細胞の鑑別 は容易であるが，顆粒を全く持たない休止期にあっては両者の識別は極めて困難 である、鑑別容易な機能状態にある腺細胞によって分布を観察するに，分布には 一定の法則がある。即ち粘液細胞は導管に続く腺管（粘液管）を構成し，漿液細 胞は末梢に存在して粘液管に開口する漿液性腺管（終末部）を作る。また分枝し た粘液管壁, 特に末端に近い壁に多くの半月が見られ, 半月は漿液細胞のみで構 成されている。

気管腺に於ける半月は Tarchetti (1871) により Giannuzzi 氏半月として初めて 報告された（半月は混合腺にて Giannuzzi (1865) が始めて観察したあのである). Tarchetti は半月構成細胞を原形質性細胞と呼んで居るが，粘液顆粒で充満され ていない細胞という意味で用いた語のようである。Stöhr (1887) は半月を分泌物 を充満した細胞（粘液顆粒を充満した細胞）によって圧排された分泌物を持たぬ 腺細胞の群であると記載したが，既に Fuchs-Wolfring（1898）によりこの意見は 否定された。彼女は気管腺に执いて，半月を構成している細胞は圧排された分泌 物空虚な細胞ではなく，分泌細管を有する漿液細胞である之主張し，乙れを Randzellenkomplex と呼んでいる。しかし彼女は Golgi 陰像を意味する分泌細管 は粘液細胞の中にはないとして居り，また当時の粘液細胞と漿液細胞は機能段階 上の時期的な差に過ぎないという思想から考えれば，大同小異の感をまぬがれな い. 著者の観察によれば, 半月を構成する漿液細胞の分泌機能は周囲の粘液細胞 の分泌機能或いは分泌周期とは全く無関係で独立して居て，両者間の移行を示す 如き所見は全くない，乙れは漿液性終末部に就いても同様である。唾液腺に於い て M. Heidenhain（1920）の考えた半月の生成に関する説は，気管腺にはあてはま らない。つまり半月は粘液化した上皮細胞に圧迫された漿液細胞群ではなく，半 
月の種々の大きさや形から考えると, 半月之漿液性終末部之の間には形態学的移 行があり, 半月は発育の悪い. 或いは未発育の状態にある漿液性腺管（終末部）で あると考えられる。

6. 筋上皮細胞。

腺細細胞の基底面と固有膜との間に多数の筋上皮細胞が存在するのが観察され た. 筋上皮細胞は汗腺, 乳腺, 唾液腺等で多く観察され, 形態学的に 2 種類に分類 される，1つは汗腺や乳腺に見られる平滑筋線維と殆ど一致する形態をとるあの で，腺管の長軸に対しやや斜好走る細長い紡鍾形の細胞であり，細胞の中央に 楕円形の明るい核を持ち, 細胞質内には筋原線維束が証明される。他は唾液腺等 に見られるもので, 細胞は分岐する突起を出し, 突起は籠形に分泌部を包むので 籠細胞之呼ばれる。筋上皮細胞は発生学的に腺細胞之起源を同じくする上皮性の あのであると考えられているが，形態的には平滑筋線維佂酷似する点で中肧葉起 源を思わせる，乙机関して Hamperl（1938）は乳腺の筋上皮細胞の增殖に就い ての研究の中で, 上皮性組織と中胚葉性組織との中間的な borderline region と屯 言うべき領域があり，それに属する細胞は両組織への分化の可能性を潜在的に持 って居り, 中胚葉性の細胞へも, また同様に上皮性細胞へ屯発展して行くてとが 出来ると考元，筋上皮細胞はそのような borderline region より生じて来たものと 考えて居るようである。

気管の筋上皮細胞に就いては Fuchs-Wolfring（1898）が僅かに固有膜の籠細胞 という表現でその存在を認めたにすぎず, 細胞内の原線維の存在等の微細構造に 関しては全く観察されていない，彼女以後（或いは彼女以前）の研究者も気管腺 の筋上皮細胞には全く触れて居らず, 気管腺の筋上皮細胞の細胞学的検索は本研 究が最初のものである。彼女は半月部に多数の籠細胞を認めた之記載している が，著者は半月のみならず粘液管及び漿液性腺管壁にも多数の筋上皮細胞を認め た。特に末梢部に多い上うである。気管腺に見られる筋上皮細胞は平滑筋線維型 のもので, Fuchs-Wolfring の見た籠細胞型のあのではない，互いに突起を多数出 して結合しているような所見は全く見当たらず，その縦断では固有膜に沿って細 長く伸び，平滑筋線維に極めて類似した像を呈するが，横断或いは斜断された場 合には腺細胞の基底部へ突出する丘状或いは三角形の小細胞として認められる. 核は細胞の長軸之平行する楕门形で明るく，横断面では円形を呈する，細胞質は 極めて明るく，鉄 hematoxylin で灰色に淡く染まる筋原線維束が細胞の長軸の方 向に走るのが見られる。横断面では固有膜側に偏し，核はその反対側にある.

\section{C. 分泌機能状態による腺細胞の細胞学的变化.}

気道諸部の腺の腺細胞の分泌機能相を細胞学的に研究した学者には, 鼻腺で岩 井 (1958), 高橋 (1961), 増田 (1962) 等が, また上靧洞腺では石井 (1954) がある が，人の気管腺の腺細胞飞就いては，2 種腺練胞の区別はなされても，それ以上， 
詳細な細胞学的観察は文献中に見当らない，鼻腺や副鼻腔腺, 噍頭腺が研㠰され ているのに気道の中であ気管腺は取り残された観がある。著者は気管腺の腺細胞 に就いて分泌機能相，それに関連する糸粒体，Golgi 装置初めて観察した。

気管腺を構成する粘液細胞と漿液細胞の腺内での分布に関して一定の法則があ ることは既に述べた。両種腺細胞は各々独立した分泌機能を営み，互いに移行す るととはない，両細胞共に分泌物空虚な機能休止期に於いては糸状或いは桿状の 系粒体を有し，核上部には染色標本では Golgi 陰像が見られ，Kolatchev 氏法では まとまった網状或いは糸球状の Golgi 装置が黒化して認められる。乙の期に於い ては粘液細胞の Golgi 装置の力が漿液細胞のものよりやや発育が悪いが, 両者の 鑑別の手掛りとなるほどの差ではなく，両者の鑑別には細胞の分布位置が重要性 を持っている．分泌機能が開始すれば両者の識別は容易となる。

分泌周期の時期的区分は鼻腺に於ける岩井 (1958) の様式に従った。鼻腺では 高橋 (1961) は電顕的に漿液細胞の分泌周期を 6 期に, 増田 (1962) は粘液細胞 の分泌周期を 8 期に分けているが，光顕的には補充期の像をそれほど細分する必 要はないように思われるので, 岩井の如く 4 期に分けた。

粘液細胞では分泌機能開始と共に Golgi 陰像内に Bauer 氏反応で紅紫色に染ま る粘液顆粒が出現し，次第に量を増して核上部 Golgi 野に顆粒集積を作り，次に 細胞先端部へ移行し，先端部に顆粒集積を形成する。乙の時期（補充期）には核 上部之細胞先端部とに $2 つ の$ 粘液顆粒集積が認められ, 普通染色では粘液顆粒が 殆ど染まらず明調であるため，2 者間に暗調な原形質が带状に残存して中間暗带 を作る，Golgi 装置は大きく網状に広がり，核上部の顆粒集積部全体に拡大する けれども, 先端部の顆粒集積部には侵入しない. 気管腺粘液細胞の補充期の Golgi 装置に就いては Järvi (1935) が観察しているようであるが，文献を入手出来ず， 詳細は不明である。系粒体は顆粒間, 中間暗帯, 基底部に多数認められる。顆粒 の産生が進み，2つの顆粒集積は増大して連続し，中間暗帯は消失し，細胞は顆 粒で充満肥大し，核は細胞の基底部に圧迫されて不整形に扁平化され，種々の程 度に濃縮する (充盈期). Golgi 装置は大きな網を核上部に広げるが，核と共に基 底部に圧迫されている像もしばしば認められる。系粒体は多数に粘液顆粒の間に 認められる。排出期には顆粒は排出され，細胞も細くなり，Golgi 装置も核に向 かって萎縮する．以上の如く粘液顆粒の形成には Golgi 装置が主として関与し， 系粒体は各期を通じてその量及び形態に大差なく，粘液顆粒形成への関与は形態 学的には証明されない。

漿液細胞には各種染色法で好染する小さい漿液顆粒が核上部の Golgi 野に先ず 現われる。次第に増量して核上部に集積し，次いで細胞先端から核上部までの間 に広く蓄積される(補充期).しかし粘液細胞に見られたような中間暗帯は明らか ではない. Golgi 装置は顆粒産生の開始と共に発達して大きい網状をなす。系粒体 にはかなり長い系状を呈するものが多く，核周囲及び基底部，核上部顆粒の間に 
あ認められ，顆粒の增量と共に系粒体は減少するように思われる，充盈期に到る と, 細胞は顆粒で充満肥大する。核は基底部に圧排されるが, 円形を保ち，圧迫に よる変形や濃縮の像は示さない, 分泌顆粒は細胞先端部のあのより次第に空胞化 して，染色性は弱まり，顆粒の集積は分泌空胞の集積之化して明るく泡沫状に見 える. Golgi 装置は極好て良く発達している。系粒体は主に基底部に認められる。 分泌空胞は細胞加ら腺腔へ突出する分泌突起内へ移行し, アポクリン分泌像が認 められる (排出期). 以上の如き分泌各期の所見から，漿液細胞に於いては，各期 の Golgi 装置の変化及び補充期に先ず顆粒が Golgi 野に出現するととから, 分泌 顆粒が Golgi 野で形成されることは疑いを入れないが，系粒体は顆粒の增加之共 に減少するが，系粒体が直接顆粒に転化する所見はなく，鼻腺（岩井 1958）に於 いて認められた如き系粒体の先端部が肥厚し離断されて顆粒が形成される像は見 出せなかった。高橋 (1961) は電顕的に鼻腺漿液細胞にて糸粒体そのものが分泌

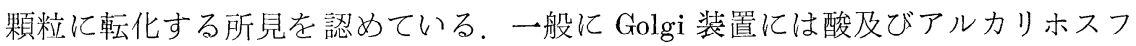
アターゼの存在が証明され，系粒体には諸種酸化䤏素や呼吸䤏素が存在すると考 えられて居り (Bourne 1955), たとえ系粒体自体が直接顆粒に転化しなくてす, 何らかの形で顆粒の形成に関係していることは漿液細胞のみならず粘液細胞に於 いてあ充分考えられる。粘液細胞では顆粒の間に多数の系粒体が散在して顆粒に 接していることは，乙れを暗示するようである。漿液細胞にて糸粒体が減少する のは，系粒体証明法の技術的欠陷によるものではないかとも想像される。

2 種腺細胞の分泌顆粒はその染色性を異にする。すなわち漿液細胞の分泌顆粒 は eosin に好染し, 鉄 hematoxylin 飞染まり, Kull 氏染色の anilinfuchsin, azan 染色の azocarmin 又は anilin 青等で強染する。他方粘液顆粒は hematoxylin, azan 染色の anilin 青で極く淡い青色に染まることはあるが，鉄 hematoxylin，Kull 氏 法では染まらず㳉るい空胞として見える。併し過沃度酸 Schiff (PAS) 法では 共に深紅色に呈色して判別不能であり，共に唾液消化耐性である。一般に PAS 反応では粘液細胞の粘液顆粒の他に漿液細胞の漿液顆粒も陽性に反応するこ之は Lillie (1949), Montagna, Chase 之 Hamilton (1951), 伊東之岩重(1953) 等により 証明されたが，著者もまたこの事実を気管腺において確認した。両種腺細胞の分 泌顆粒の鑑別には Bauer 氏反応が適している. Bauer 氏反応では粘液顆粒は強く 紅紫色に染まるが，漿液顆粒は淡く紅紫色を呈し見分けは容易である。併し両種 腺細胞の鑑別には顆粒の組織化学的検索のみではなく, 形態的観察が必要なと之 は前述の通りである。

Kolatchev 氏法に依る標本に於いて，導管の円柱上皮細胞と分泌部の両種腺細 胞の細胞質内にオスミウム酸で黒化する脂肪滴を認めた。乙れは Levi 氏固定標 本であオスミウム酸で黒化証明される，多くは核上部で Golgi 野内或いは Golgi 野に接して存在し, 時に細胞基底側, 核周囲にも見られる。導管円柱上皮細胞に は脂肪滴は少ないが，腺細胞ではかなり多量の脂肪滴（或いは脂肪小体）が存在 
することがあり, Golgi 野を離れて粘液細胞の先端部顆粒集積の中や, 漿液顆粒 の間にも分布するのを見るととがある。しばしば 1 一数個の空胞を含み, 単胞性 或いは多胞性の脂肪滴として観察された。岩重 (1952) は, 高年者エックリン汗 腺細胞で多くの有胞性脂肪滴が出現し, Golgi 装置の発育の悪いのを見て, Golgi 装置の脂肪化を提唱した。伊東と渡 (1958) は青壮年者の Langerhans 氏島細胞に て同様の有胞性脂肪小体を認め, Baker の Lipochondria はこの有胞性脂肪小体に

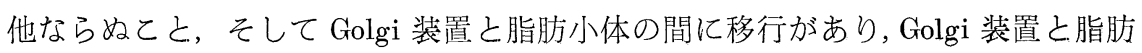
小体の量の間には反比例関係があることを確認し, 岩重の Golgi 装置の脂肪化説 を承認したが，乙れが老人性変化ではないという結論に達した。著者も気管腺の 腺細胞に於いて, 有胞性脂肪小体の多い細胞では Golgi 装置の発達が悪く殆で認 められぬものすらあることを知った。 上皮細胞に於ける脂肪小滴の出現は, 汗腺 細胞や Langerhans 氏島細胞のみならず, 食道腺の導管上皮及び腺細胞（横地 1954), 鼻腺の導管及び腺細胞 (岩井 1958) 等, 多くの腺に於いて観察されている.

\section{IV. 結 語.}

人の気管腺の組織学的研究は少なくないが, 細胞学的研究に到っては報告が無 いまま今日に及んでいる。著者は25例の健常な人気管粘膜を手術時に採取し，気 管腺の組織学的細胞学的観察を行ない, 次の如き所見を得た。

1. 人の気管腺は粘膜下層にあり, 軟骨部では表面と平行に, 軟骨間部と膜性 壁では垂直或いは斜めに深部へ広がるものが多い.

2. 気管腺は粘膜表面上皮の漏斗状管状の陥山の底に開口する。陥凹は時に 分岐する。

3. 気管腺はすべて導管を持つ。導管の管腔は広く，1層の円柱上皮細胞とそ の基底部にある基底細胞より成る 2 列上皮で囲まれ，しばしば 1 次的に分岐する. 導管はすべて上皮陌凹底に開口する。

4. 導管に続く分泌部は先ず 1 層の粘液細胞で囲まれる太い粘液管で, 数次に 亘って分岐して次第に細くなる。粘液管から 1 層の漿液細胞で囲まれた短い管状 か胞状の漿液性腺管, または終末部が出て, てれも屢々分岐する。従って人の気 管腺には純粘液腺も純漿液腺むなく, 総て混合腺であり, 単分岐管状胞状腺或い は複分岐管状胞状腺である。

5. 腺の分岐に於ける 粘液細胞と漿液細胞の分布には一定の法則があり, 粘液 細胞は導管に続く腺の開口部に近い位置を占め, 漿液細胞は腺の分岐の末梢部に 分在し, 開口部加らは遠い位置を占める。数次に亘って分岐する粘液管は粘液の 分泌を行なうと共に，導管の役割も行なう.

6. 気管腺には種々の大きさと形を持つ多数の半月がある。粘液管壁に附属し， 1 つの粘液管の末端に数䇢の半月が並ぶことがある。大きい半月は粘液管壁より 胞状に突出して，深い内腔を有し，漿液性腺管か終末部への移行を思わせる，半 
月は発育の悪い漿液性腺管或いは終末部である。半月を形成する漿液細胞は漿液 性腺管または終末部の漿液細胞と形態的に一致し，同じ分泌像を示す。

7. 腺管壁の腺細胞と固有膜の間に, 腺管の長軸と殁ど平行して走る平滑筋線 維型の筋上皮細胞を多数認める。明るい楕円形の核を有し, 筋原線維束が証明さ れる。

8. 導管円柱上皮細胞之腺細胞に系状或いは桿状の系粒体之網状の Golgi 装置 を証明した。導管上皮細胞には分泌像は認めなかった。腺細胞には分泌像が認め られるが，機能休止期の粘液細胞之漿液細胞とは分布位置による以外には鑑別は 極めて困難であり，分泌活動を行なっている細胞では，産生された分泌顆粒の染 色性, 集積状態, 顆粒が充満した時期の核の形態的変化等により, 容易に鑑別出 来る。両種腺細胞の間に移行はない，両種腺細胞の分泌周期は，分泌顆粒空虚な 機能休止期, 補充期, 充盈期, 排出期に分けられ, Golgi 装置と糸粒体はそれら の時期に応じて変化する。顆粒形成は両種腺細胞に於いて Golgi 野内で行なわれ る。系粒体から分泌顆粒が直接形成されるととを証明する形態的所見はない．漿 液細胞では分泌顆粒が分泌空胞となり，腺腔へ出される突起を充たし，アポクリ ン分泌によって排出される像が屡々見られた，気管腺の両種腺細胞の分泌顆粒は 共に PAS 反応強陽性, 唾液消化耐性である，Bauer 氏反応では漿液顆粒の染色性 は弱く，両種腺細胞の鑑別に有効である.

9. 導管円柱上皮細胞及び腺細胞にはオスミウム酸で黒化する脂肪滴が屡々出 現する，主に Golgi 装置に近接して存在し，空胞を含み，所謂有胞性のものがあ る.

擱筆するに当たり，恩師石井英男教授並びそ第 1 解剖学教室伊東俊夫教授の御懇篤なる 御指導と御校閲を深謝し, また御協力をいただいた第 1 解剖学教室諸先生飞謝意を表します。

\section{Author's Abstract.}

Since the last century, histological studies on human tracheal glands have been carried out not infrequently, but nevertheless the cytological details and their changes accompanying the secretory function still remain in perfect obscurity. The author obtained in operations healthy tracheal mucosae from 25 cases, and performed histological and cytological observations on the tracheal glands. The samples were fixed in LEVI's and CHAMPY's fluids, ZENKER-formol, 10\% formol and formol-alcohol, embedded in paraffin, and serially sectioned 3-4 $\mu$ thick. For staining, hematoxylin (HANSEN)-eosin, HEIDENHAIN's iron-hematoxylin, azan, periodic acid-SCHIFF (PAS) reaction and BAUER's reaction were employed. The GOLGI apparatus was visualized by KOLATCHEV's osmic acid method, and sometimes further stained with KULL's method. The results are summarized as follows:

1. The human tracheal gland is mainly found in submucosa, and extends in different ways in the cartilaginous region, intercartilaginous region and paries membranaceus, In the cartilaginous region, it spreads parallel to the surface, and in the 
intercartilaginous region and paries membranaceus, it spreads in most cases into the deep layers perpendicular or oblique to the surface. In this way, the shape and the location of the gland is dependent on the presence of the tracheal cartilage.

2. The gland opens in the bottom of the tubular or funnel-shaped crypt of the tracheal mucosa, lined by the same pseudostratified columnar ciliated epithelium like the surface of the mucosa. The crypts sometimes show at the bottom simple branching.

3. All the tracheal glands are provided excretory ducts with wide lumina, lined by a simple columnar epithelium consisting of a single layer of high columnar epithelial cells and a layer of basal cells in its base. Sometimes the excretory duct shows a simple branching. The striated portions, as found in the ducts of the large salivary glands, are not visible.

4. Secretory portion directly continuous with the excretory duct is a large mucous glandular tubule which ramifys several times into small mucous branches. In the mucous tubule and its branches open many tubular and alveolar albuminous (serous) secretory portions (terminal portions), which consist of albuminous glandular cells and also ramify. The human tracheal glands are therefore neither pure mucous nor pure serous (or albuminous) glands, but are always mixed glands, and from morphological standpoint they should be called simple and sometimes compound branched tubuloalveolar glands.

5. Concerning the distribution of both mucous and albuminous cells in the branched glandular tree there exists a definite rule: the former being situated near the excretory duct occupying the proximal portion, and the latter being distributed in the more distal part making the terminal portions of the tree. The branched mucous tubule consequently not only secretes mucous secretion but also serves as a part of the excretory duct. Numerous demilunes, consisting of albuminous cells, are found in the wall of the branched mucous tubule.

6. The tracheal gland has many demilunes of variable shapes and sizes, and in some occasions several demilunes are grouped at the end of the mucous tubule. Larger demilunes of alveolar form protrude often from the mucous tubule wall into the interstitial connective tissue, including deep lumina. These findings suggest the transition of demilunes into albuminous tubules or acini. Demilunes are considered to be poorly developed albuminous tubule or acini and present the same cytological changes in secretory function.

7. Between the basal surface of the glandular cells (mucous and albuminous) and the membrana propria of the glandular tubules, there are many myoepithelial cells, which are of smooth muscle fiber type and arranged in parallel with the long axis of the glandular tubule. They have a long elliptic nucleus and myofibrill bundle, running parallel with the long axis of the cell, in the clear cytoplasm.

8. In columnar epithelial cells of the excretory duct and glandular cells, filamentous or rod-shaped mitochondria and reticular GOLGI apparatus are seen. Secretory activity is not revealed in the epithelial cells of the excretory duct, the secretory phenomena, however, are morphologically detected from stage to stage in two kinds of glandular cells. In the resting and empty stage, it is difficult to differentiate mucous cells from albuminous cells except by their localization, but in secretory active stages, two kinds of cells are easily differentiated by stainability of secretory 
granules, the mode of their accumulation in cytoplasm, the degree of the morphological change of the nucleus in the cell filled with secretory granules (secretion-loaded cells) and so on. There is no transition between two kinds of glandular cells. The secretory cycle of the two cell types falls into the following 4 stages or phases: resting or empty phase, restitution phase, loaded phase and excretory phase. GOLGI appartus and mitochondria undergo changes in accordance with these phases. Secretory granules of both kinds of cells (mucous and albuminous granules) are elaborated in the GOLGI apparatus. The cytological findings, which suggest the transformation of mitochondria into secretory granules, however, are not found. In the albuminous glandular cells the granules are transformed into the secretory vacuoles in the apical zone of the cytoplasm and go into the cytoplasmic process protruded into the secretory cavity. In this way the process filled with secretory vacuoles is pinched off and shows the picture of apocrine secretion. The secretory granules of the two kinds of glandular cells of the tracheal gland are both strong PAS-positive, though revealed both not to be glycogen. The BAUER's reaction results far stronger in the secretory granules of the mucous cells as in those of the albuminous cells. So this reaction is most usefull for the differentiation of both cell types.

9. In epithelial cells of the excretory duct and glandular cells are observed lipoid granules blackened by osmic acid. They are found mainly near the GOLGIzone. They contain often one or more small vacuoles and appear as mono- or polyvesicular fat droplets.

\section{文献.}

安藤鎮雄 : 気管立びそ気管支壁の組織発生, 特飞との結合組織線維の態度飞就いて。熊 本医学. 34 (1960). 頁 184-196. - Barg mann, W.: Luftröhre und Bronchien. Histologie und mikroskopische Anatomie des Menschen. 3 Aufl. 1959. S. 511-513. - Bourne, G. H. : Some chemical and biochemical aspects of the Golgi apparatus. J. Roy. Micr. Soc. 74 (1954). P. 180187. - Emery, J. L. and A. Mithal : Development of the mucous glands in the trachea. Proc. Roy. Soc. Med. 54 (1961). P. 1016-1017. - Frankenhäuser, C. : Untersuchungen über den Bau der Tracheo-bronchialschleimhaut. Inaug.-Diss. Dorpat. 1879. (Heiss 引用). 一 FuchsWolfring, S.: Über den feineren Bau der Drüsen des Kehlkopfes und der Luftröhre. Arch. mikr. Anat. 25 (1898). S. 735-761. - Ham, A. W. and T. S. Leeson: The respiratory system. Histology 4th Ed. 1961. P. 663-691. - Hamperl, H.: Über die Myothelien (myoepitheliale Elemente) der Brustdrüse. Virchows Arch. 305 (1939). S. 171-215. 一橋本泰彦：気管及び気管 支学, 解剖と生理. 耳鼻咽喉科学 (後藤敏郎監修). 下巻. 1960. 頁 1259-1271. 一 Heidenhain, A. : Über die acinösen Drüser der Schleimhäute, insbesondere der Nasenschleimhaut. Dissertation Breslau. 1870. (Fuchs-Wolfring 引用) - Heidenhain, R.: Physiologie der Absonderungsvorgänge im Handbuch der Physiologie. Bd. 5. Leipzig. 1883. (Fuchs-Wolfring 引用). 一 Heidenhain, M. : Neue Grundlegungen zur Morphologie der Speicheldrüsen. Anat. Anz. 52 (1920). S. 305331. - Heiss, R. : Luftröhre. (Hrsg. v.) Möllendorff : Handbuch der mikroskopischen Anatomie des Menschen. Bd. 5, Teil 3. 1936. S. 742-750. - Hioki, K.: Zytologische Untersuchung über das Flimmerepithel der menschlichen Trachea mit besonderer Berücksichtigung der Beziehung zwischen Flimmer- und Becherzellen. Cytologia. 12 (1942). S. 326-346. 一石井英男 : 上顎洞粘膜 飞関する実験的研究. I. 犬の上顎洞粘膜の腺飞ついて。日耳鼻. 57 (1954). 頁. 254 . 一伊東 俊夫：バウェル氏反応よる細胞内クリコーグン，粘液物質とゴルヂ装置，ミトコンドリアの 
同時証明法. 臨床慶林. 2 (1940). 頁. 451-460. 一 プレパラート製作法. 1955. 一 伊東俊夫 と岩重 毅：健康な高年者の腋窩アポクリン汗腺の細胞学的組織学的研究. 日組録. 5 (1953). 頁. 455-476. 一伊東俊夫と渡仲三：人の萃臓 Langerhans 氏島細胞の Golgi 装置飞ついて. 日 組録. 14 (1958). 頁. 369-386. 一岩井宏方：人鼻腺の形態学的研究. 日耳鼻. 61 (1958). 頁. 14521473. 一岩重 毅：健康な高年者の腋窩エックリン汗腺の細胞学的組織学的研究. 日組録. 4 (1952). 頁. 75-90. - Järvi, O.: Der Bau der Trachea- und Larynxdrüsen und der Drüsenzellen bei einigen Säugetieren. Die Bedeutung des Golgi-Apparates und anderer Zellkomponenten für den Sekretionsprozess : Adenomerentheorie. Ann. Acad. Sci. Fennice Ser. A 43, 1 (1935). (Hirsch, G. C.: Form- und Stoff wechsel der Golgi Körper. 1939. Protoplasma- Monographien Bd. 18. 引用) Kanthack, A. : Studien über die Histologie der Larynxschleimhaut. 1890. (Fuchs-Wolfring 引用). 一増田隆正：人鼻腺粘液細胞の電子顕微鏡的観察. 日耳鼻. 65 (1962). 頁. 955-976. 一 Maximow, A. and W. Bloom : Respiratory system. Textbook of Histology. 1960. P. 430-449. Montagna, W., H. B. Chase and J.B. Hamilton: The distribution of glycogen and lipids in human skin. J. Invest. Derm. 17 (1951). P. 147-157. 一森 優：気管及び気管支の構造. 気管及び気管支の発生. 日本耳鼻咽喉科全書。巻 3. 冊 3. (1952)。頁. 39-48. 一 Przew oski, E. : Über die Divertikel der Trachea. Arch. Laryng. Rhinol. 8 (1898). S. 422-461. - RauberKopsch: Lehrbuch und Atlas der Anatomie des Menschen. 19. Aufl. Bd. 2. 1955. S. 151. Rhodin, J. and T. Dalhamn : Ultrastructure of the tracheal ciliated mucosa in rat and man. Ann. Otol. 68 (1959). P. 964-974. - Schaffer, J.: Die heterokrinen oder gemischten Drüsen. (Hrsg. v.) Möllendorff: Handbuch der mikroskopischen Anatomie des Menschen. Bd. 2, 1. Ht. (1936). S. 182-194. - Schumacher, S.: Histologie der Trachea und der Bronchien. (Hrsg. v.) Denker-Kahler : Handbuch der Hals usw.-Heilkunde. Bd. 1 (1925). S. 399-405. 一鈴木成昌 : 人 鼻腺排泄道の形態学的研究. 日耳鼻. 64 (1961). 頁. 838-847. 一高橋徳三郎：人鼻腺漿液細 胞の電子顕微鏡的観察。日耳鼻。 64 (1961). 頁. 50-66. - - Tarchetti, P.: Sulla struttura delle ghiandole mucipare della trachea. Torino 1875. Die Resultate waren schon vorher auszugsweise in der Rendiconti dell' Instituto Lombrardo 1871 publiciert worden. (Fuchs-Wolfring 引用). - Thurlbeck, W. M., B. Benjamin and L. Reid : Development and distribution of mucous glands in the foetal human trachea. Brit. J. Dis. Chest. 55 (1961). P. 54-64. 一 Thurlbeck, W. M., B. Benjamin and L. Reid : A sampling method for estimating the number of mucous glands in the foetal human trachea. Brit. J. Dis. Chest 55 (1961). P. 49-53. - Waller, C. und G. Björkman : Studieren über den Bau der Trachealschleimhaut mit besonderer Berücksichtigung des Epithels. Biol. Unters. v. Retzius 2 (1882). S. 71. (Fuchs-Wolfring 引用) 一渡辺修一：人 体気管粘膜の基底膜飞関する形態学的研究. 日大医学. 15 (1956). 頁. 872-877. 一横地千仍 : 人腸粘膜の細胞学的研究. III. 十二指腸腺について. 日組録. 2 (1951). 頁. 13-27. 一横地千 伋, 成田安弘, 牧野アツ: 人の食道腺の細胞学的研究. 人の食道腺は粘液腺か或いは混合腺 か？日組録. 6 (1954). 頁. 197-212. 一吉岡才：鬼気管炶膜上皮細胞飞関する電子顕微鏡的 研究. 大阪市立医学誌. 10, 補 1 (1960). 頁. 315-320. 